\title{
ENHANCING THE LEGAL PROFESSION'S CAPACITY FOR INNOVATION: THE PROMISE OF REFLECTIVE PRACTICE AND ACTION RESEARCH FOR INCREASING ACCESS TO JUSTICE
}

\author{
Michele M. Leering*
}

Recent national reports have documented growing justice gaps in Canada and have identified a compelling need for innovation in the justice sector to better meet the needs of the public. Nurturing a greater capacity for individual, collective, and critical reflection will ensure the legal profession is much better equipped to respond creatively and strategically to a lack of equal access to justice. In this article, I explore the generative and transformative potential of reflective practice - an important professional competency in other professional disciplines, but under-theorized in law, and action research - a dynamic and flexible form of qualitative research for supporting a culture of innovation in the legal profession and the justice system. Reflective capacity is a crucial enabler of innovative thinking, and it undergirds approaches to encouraging individual and systems change emerging from the organizational learning and innovation literature. An enhanced capacity for reflection will also support more generative and "futureforming" dialogues within the profession and between justice system stakeholders. Furthermore, systematically reflecting on disorienting empirical data about the troubling state of access to justice could develop an "access to justice consciousness" in law students and legal professionals, leading to a stronger willingness to take action to narrow the justice gaps. Introducing action research as an unpretentious and effective enabler of profound transformation and innovation in individual and organizational practices offers significant promise for tackling the "wicked problem" of access to justice. Practical illustrations of action research as an enabler of innovation drawn from legal practice are provided.

De récents rapports font état de lacunes croissantes du système de justice canadien et de la nécessité impérieuse d'innover dans le secteur de la justice afin de mieux répondre aux besoins du public. S'ils ont une plus grande capacité de s'engager dans un processus de réflexion individuelle, collective et critique, les membres de la profession juridique seront beaucoup mieux outillés pour réagir de façon créative et stratégique aux iniquités inhérentes à l'accès à la justice. Dans cet article, j'explore les possibilités de création et de transformation de la pratique réflexive, soit une compétence professionnelle qui a acquis beaucoup d'importance dans d'autres disciplines professionnelles mais qui n'est pas suffisamment enseignée en droit, et de la recherche-action - soit une forme de

(BA, LLB, MAdEd) PhD candidate, Faculty of Law, Queen's University, Kingston; Executive Director/Lawyer, Community Advocacy \& Legal Centre, Belleville, ON. I would like to thank Nicole Aylwin, the Honourable Thomas Cromwell, Claire Carroll, and Brea Lowenberger, for their insightful comments on early drafts of this article, and Rebecca Noble for the able, technical, timely, and thoughtful assistance she provided. 
recherche qualitative souple et dynamique servant à appuyer l'innovation au sein de la profession juridique et du système de justice. La capacité réflexive constitue un facteur habilitant crucial de la pensée innovatrice et le fondement d'approches susceptibles de promouvoir les changements individuels, organisationnels et systémiques émergeant de la littérature sur l'apprentissage organisationnel et l'innovation. Une plus grande capacité de réflexion favorisera également un dialogue plus créatif et plus "visionnaire» au sein de la profession et entre les intervenants du système de justice. Qui plus est, une réflexion professionnelle systématique sur les renseignements déstabilisants au sujet de l'état de l'accès à la justice pourrait mener à une prise de conscience chez les étudiants en droit et les juristes, voire à un plus grand désir d'agir pour combler les lacunes sur le plan de l'accès à la justice. La recherche-action représente une façon simple et efficace de créer une profonde transformation des pratiques individuelles, organisationnelles et institutionnelles et, dans ce contexte, elle pourrait être une solution prometteuse à explorer pour atténuer ce qui a été décrit comme le " problème pernicieux» de l'accès à la justice.

\section{INTRODUCTION}

To become more responsive to the current challenges in access to justice - an imperative that renowned socio-legal scholar Richard Abel has described as the most fundamental ethical challenge facing the profession - current and future legal professionals need to become more reflective and innovative in their practices. ${ }^{1}$ This imperative holds true for whatever these diverse forms of legal practice might include, whether they involve teaching, directly serving clients, operating law offices, administering and designing court and dispute resolution systems, offering public legal education, or undertaking judicial duties, policy-making or other legal professional roles. Yet the Canadian Bar Association [CBA] warns that the justice system's capacity for innovation is "underdeveloped and undernourished"2 and that the legal profession lacks a "culture of innovation." 3 This concern is echoed by the national Action Committee on Access to Justice in Civil and Family Matters (Action Committee) in their groundbreaking report ${ }^{4}$ and their ongoing work to build a Canadian access to justice movement. Legal

1 Richard L Abel, "An Agenda for Research on the Legal Profession and Legal Education: One American's Perspective" in Hilary Sommerlad et al, eds, The Futures of Legal Education and the Legal Profession (Oxford: Hart, 2015) 201 at 216 (stating that "unequal justice is not lesser justice; it is injustice").

2 Canadian Bar Association (CBA), Reaching Equal Justice Report: An Invitation to Envision and Act (Ottawa: CBA, 2013) at 137, online:

$<$ www.cba.org/CBAMediaLibrary/cba_na/images/Equal\%20Justice\%20\%20Microsite/PDFs/EqualJusticeFinalReporteng.pdf> [CBA, Equal Justice].

3 CBA, Futures: Transforming the Delivery of Legal Services in Canada (Ottawa: CBA, 2014) at 27, online:

$<$ www.cba.org/CBAMediaLibrary/cba_na/PDFs/CBA\%20Legal\%20Futures\%20PDFS/Futures-Final-eng.pdf> [CBA, Futures].

4 Action Committee on Access to Justice in Civil and Family Matters, Access to Civil and Family Justice: A Roadmap for Change (Ottawa: Action Committee on Access to Justice in Civil and Family Matters, 2013), online:

$<$ flsc.ca/wpcontent/uploads/2014/10/ACCESSActionCommFinalReport2013.pdf> [Action Committee, Roadmap for Change]. 
professionals must become more "nimble, mobile, and innovative as the role of a lawyer is redefined": the CBA cautions that the future relevance and viability of the profession hangs in the balance. ${ }^{5}$

This article explores the promise that "reflective practice" and "action research" offer for fostering a culture of innovation in the legal profession and the justice sector. I believe that cultivating reflective practice beginning in law school and encouraging legal professionals and the organizations they work for to use action research strategies will synergistically contribute to a more reform-oriented and responsive legal culture and justice system. "Legal professionals" is inclusively defined here to include law students, legal educators, ${ }^{8}$ lawyers, judges, policy-makers, mediators, government and court staff, and other legal practitioners. Each of these justice sector roles shares a common professional interest and responsibility to ensure equal access to justice and to create a more just society through the rule of law. Regardless of the specific professional role, engaging in reflective practice and action research encourages curiosity, open-mindedness, innovative thinking, and experimentation and will be transformative for all roles. Our experiences in implementing reflective practice and action research newly articulated professional capacities - will challenge our assumptions about how professionals learn and develop and about how professional knowledge is generated.

This article considers how we might build a stronger "reflective muscle" to ensure all legal professionals become more reflective - particularly, critically reflective - about our work. This includes questioning our professional values, what we believe and understand about access to justice, and broadening our base of actionable knowledge and innovative practices through action research. How can reflective practice and action research help us to question the efficiency and effectiveness of how we practise and help us to conduct practice-based research? How can empirical research studies help us to better understand the legal needs of the public and how to meet them? Can we move towards a greater evidence-based orientation in our work? How might reflective practice and action research support change in the legal profession and our institutions, unlock our creative intelligence, and increase our ability and willingness to take action on narrowing justice gaps?

Before examining the promise of reflective practice and action research, I set out some of the context for increasing the legal profession's capacity for innovation that motivated this article. I then review some of the ways that the profession already contributes meaningfully to innovation to overcome the negative perception that it is an entirely new challenge for the profession. I also comment on how my

CBA, Futures, supra note 3 at 27.

6 Reflective practice, also known as reflective inquiry or reflective professionalism, is a term well understood in other professional disciplines and is further defined in Part II below. Donald Schön is credited with initially developing this term to describe how members of a profession build their professional expertise by creating knowledge through tacit and explicit reflection. For a more in-depth discussion and a working conceptualization of reflective practice unique to law, see Michele M. Leering, "Conceptualizing Reflective Practice for Legal Professionals" (2014) 23 JL \& Soc Pol'y 82 [Leering, "Reflective Practice"]; Michele Leering, "Integrated Reflective Practice: A Critical Imperative for Enhancing Legal Education and Professionalism" (2017) 95:1 Can Bar Rev 47 [Leering, "Integrated Reflective Practice"].

7 Action research, explored in Part III below is commonly associated with the work of Kurt Lewin. It is a form of inductive research that is used when there is a need to better understand a problem, while simultaneously seeking to create the necessary change to improve the situation as part of the research process.

8 Legal educators are also broadly defined to include all those who instruct in university law schools whether they are law professors, adjunct professors, clinical legal educators, lecturers, teaching librarians, or instructors. 
own experience as a lawyer has informed my perception of the benefits of these strategies for increasing access to justice.

The context and the imperative for action are crucial - two influential national reports have encouraged the profession to respond urgently and strategically to the unmet "everyday legal problems" of Canadians, to the growing justice gaps, and to a documented lack of equal justice. ${ }^{9}$ Legal professionals need new skills and capacities to respond to the emerging empirical research about unmet legal needs and the "law as lived"10 and a predicted future "unrelenting, dynamic and transformative change" 11 for the profession. The Action Committee insists that "[a] new way of thinking - a culture shift - is required to move away from old patterns and old approaches" to support a new culture of reform. ${ }^{12}$ Six guiding principles are offered for shifting "professional consciousness": "put the public first"; "collaborate and coordinate"; "prevent and eradicate"; simplify the justice system; "take action"; and "focus on outcomes." 13

Our legal training has not prepared us sufficiently for taking professional action - including reflection - on these principles. To act on these six principles means re-examining the kinds of legal assistance and services that are needed, grounding our thinking in empirical research about legal needs, and envisioning new roles and responsibilities for legal professionals within a more responsive justice system. Responding effectively requires an increased capacity to innovate and collaborate throughout the justice sector. As a result, these six principles have implications for the design of legal education at every stage of professional learning. These principles also imply a need for change in legal practice, to how legal aid and other services are designed to narrow justice gaps, and to how the justice system functions.

Both national reports called on legal educators to recognize their crucial role as facilitators of a new culture of innovation. The Action Committee encouraged all legal education providers - law school, bar admission programs, and continuing legal education providers - to put a "modern access to justice agenda at the forefront of Canadian legal education" as a crucial component of the "new legal reform culture." 14 Reflective practice and action research provide two related learning theories and practical methods (largely developed by other professional disciplines) that could help the profession strengthen its capacity to tackle the "wicked problem" of access to justice, as it was described in the Reaching Equal Justice Report. ${ }^{15}$

9 Action Committee, Roadmap for Change, supra note 4; CBA, Equal Justice, supra note 2.

10 "Law as lived" is a term attributed to Roderick A Macdonald. Cited in Nathalie Des Rosiers, "Confidentiality, Human Relationships, and Law Reform” in Christine M Koggel, Allannah Furlong \& Charles Levin, eds, Confidential Relationships: Psychoanalytic, Ethical and Legal Contexts (New York: Rodopi, 2003) 229.

11 CBA, Futures, supra note 3 at 10.

12 Action Committee, Roadmap for Change, supra note 4 at 5.

13 Ibid at 6-8. I am grateful to Nicole Aylwin for the expression "professional consciousness." See Nicole Aylwin \& Trevor CW Farrow, Access to Justice, Professional Consciousness and Legal Education (Toronto: Winkler Institute for Dispute Resolution, 2014), online:

<www.cfcjfcjc.org/sites/default/files//docs/2014/Aylwin\%26Farrow_CALT_2014_slides.compressed.pdf>.

14 Aylwin \& Farrow, ibid at 21.

15 CBA, Equal Justice, supra note 2 at 126. The report defined wicked problems as "difficult to clearly define: the nature and extent of the problem depends on who is asked as different stakeholders have different views of what the problem is. They are often interdependent or co-exist with other problems and there are multiple causal factors. They go beyond the capacity of any one organization to understand and respond to. There is often disagreement about the causes of the 
Although the legal profession and legal culture have been characterized as resistant to change and innovation, members of the profession do have a history of innovating in diverse ways. We must now build on this positive momentum. Critically reflective legal scholarship has contributed to advancing equal justice for many historically disadvantaged groups. Defining access to justice more broadly than as, simply access to the courts and to lawyers, as the national reports do, has been a form of "intellectual innovation." This expanded understanding builds on legal scholarship expanding the meaning of access to justice that goes back decades. ${ }^{16}$ The recent national reports essentially popularized this scholarship and the empirical findings of legal needs research - a new trend in legal scholarship - catalyzed by a landmark study in 1999 from the United Kingdom. ${ }^{17}$ When the concept of access to justice expanded beyond courts and traditional reactive legal services, this provoked new ways of thinking about how the justice system should work and challenged assumptions about the outcomes the justice sector should be expected to produce. This has led to recommendations for designing proactive systemic solutions to minimize the disruptive and spiralling impact of legal troubles, developing approaches for the early resolution of legal problems, making dispute resolution and the justice system more accessible, and devoting new resources to increasing legal literacy and legal capability, in addition to other approaches. ${ }^{18}$

Furthermore, despite being criticized in recent years for a lack of innovative thinking, members of the profession have a proud record of critique of legal institutions and the law, undertaking socio-legal research, and advancing critical legal theory. Legal professionals have been involved in progressive law reform initiatives and test cases, designing new legal instruments, introducing mediation as an alternative to court-based dispute resolution, creating new forms of legal practice like collaborative law, and being the genesis of progressive movements for change. However, what is needed now is a more systematic approach to current challenges - creating the capacity and desire for innovation across the entire legal profession and in the broader justice sector - to build on the best of what the profession has to offer. Furthermore, we could generate a stronger momentum for ongoing reform by cultivating an "access to justice consciousness" thereby strengthening the willingness to act on these challenges.

problems and the best way to tackle them. Usually, part of the solution to wicked problems involves changing the behaviour of groups of people or all members of society." Ibid [footnote omitted], citing Australian Public Service Commission, Tackling Wicked Problems: A Public Policy Perspective (2008), online:

$<$ www.apsc.gov.au/_data/assets/pdf_file/0005/6386/wickedproblems.pdf $>$.

16 Rod Macdonald, "Access to Civil Justice" in Peter Cane \& Herbert M Kritzer, eds, Oxford Handbook of Empirical Legal Research (New York: Oxford University Press, 2010) 492 (and the five waves of access to justice); M Cappellitti \& B Garth, Access to Justice: A World-wide Survey (Milan: Sitjhof, 1978).

17 Hazel Genn, Paths to Justice: What People Do and Think about Going to Law (Oxford: Hart Publishing, 1999).

18 CBA, Equal Justice, supra note 2; Action Committee, Roadmap for Change, supra note 4; for an international perspective, see Pascoe Pleasance et al, Reshaping Legal Assistance Services: Building on the Evidence Base: A Discussion Paper (Sydney South, Australia: Law and Justice Foundation of New South Wales, 2014).

19 This neologism has been coined to capture an evolving, formative, and normative concept about the profession's responsibility to be aware and act to ensure equal access to justice. An "access-to-justice conscience" might further suggest the responsibility to take action. Other professions have developed terms to capture their aspirational expectations about justice, seeking behaviour relevant to their professional services. "Occupational justice" is an evolving term that acts as a rallying call for occupational therapists to advocate professionally for the rights, 
My perspective on the promise of reflective practice and action research is informed by my legal professional experience as an executive director and a lawyer with a non-profit community-based legal clinic in Ontario. We provide responsive legal services in a manner that aligns with the findings of the legal needs studies and the Reaching Equal Justice Report. Our services endeavour to respect the principles articulated by the national Action Committee: our clinic's mandate includes fostering access to justice and resolving everyday legal problems. Mainly funded by Legal Aid Ontario, our staff provide legal services to vulnerable and underserved populations living in small urban, rural, and remote communities in Eastern Ontario with a social justice orientation. ${ }^{20}$ Our legal staff must proficiently deliver traditional legal services while also becoming skilled in "alternative" forms of legal practice. Our practice includes triaging legal problems; providing holistic legal referrals, information, and advice; and building partnerships with "trusted intermediaries" to intervene early to prevent legal problems from escalating in our clients' lives. ${ }^{21}$ We also work to increase legal literacy and legal capability in our communities by providing educational resources, workshops, and social networking and Internet-based strategies; managing diverse projects designed to increase access to justice and increase legal empowerment; engaging in community development and systemic advocacy work; and undertaking law reform activities, including test case litigation. Our professional training did not prepare us for the challenges of practising law differently from traditional lawyering: reflective practice and action research have emerged as critical to our success in our work.

These ways of practising law differently resonate with the national reports' vision of how new professional roles are envisioned, and how the justice sector needs to be redesigned to meet current and future legal needs, to "put the public first." We discovered that individual and collective reflective practice enhances our capacity to do this work more creatively and effectively despite a fiscal environment of ongoing constrained resources. Operating like a small law firm, we embed action research strategies in our internal work processes to improve our efficiency (reducing costs and time spent on cases, realigning roles to least cost for task, streamlining work flows, and so on). This allows us to re-allocate resources to systemic work to enhance our impact. Furthermore, undertaking community-

responsibilities and liberties that enable people to experience health and quality of life as an engagement in meaningful occupations. See Lynda Wolf et al, “Applying an Occupational Justice Framework" (2010) 12:1 Occupational Therapy Now 115. Similarly, in the medical and other health professions, concepts of "health inequity" or "health inequality" concepts capture concerns about a disproportionate disease burden or risk factors based on factors including in the social determinants of health like socio-economic status, race or ethnicity, or sexual orientation. See, eg, Sara N Bleich et al, "Health Inequalities: Trends, Progress, and Policy" (2012) 33 Annual Rev Public Health 7.

20 More details about our work in three counties of Eastern Ontario can be found online: $<$ www.communitylegalcentre.ca $>$. Our legal clinic is one of a system of more than seventy such clinics across Ontario.

21 Trusted intermediaries is a term I first came across in the Linguistic and Rural Access to Justice Project. See Karen Cohl \& George Thomson, Connecting across Language and Distance: Linguistic and Rural Access to Legal Information and Services (Toronto: Law Foundation of Ontario, 2008) at 44, online: <www.lawfoundation.on.ca/wpcontent/uploads/TheConnecting-Report.pdf $>$. I now define this term to include everyone who connects people to the help that they need when they experience justiciable problems. Legal need studies have identified that people most often go to relatives, friends, and neighbours and members of the helping professions, and less often to lawyers. All of these helpers can be considered trusted intermediaries. See Michele Leering, "Navigating with the Wandering Lost: The Critical Role of Trusted Intermediaries in Increasing Access to Justice" (June 2013), online: <prezi.com/3vt4ni2zmez1/ilagpresentationfor-ilag-website-june-14-2013/> [Leering, "Trusted Intermediaries"]. 
based action research results in more responsive legal services and provides opportunities to create positive change within our communities. This has reduced the need for litigation, resolved legal appeals earlier, and helped us to develop more proactive approaches to the legal and human rights problems faced by people living on a low-income, and to increase access to justice. Reflective practice and action research now inform our current efforts to work in the "access to justice sector" in more collaborative ways. ${ }^{22}$

In the next section, I briefly introduce reflective practice as a professional capacity for legal professionals and review important aspects of reflective practice that build capability for innovative thinking and the motivation to take action. In the third section, I discuss the use of action research - a highly adaptable research-in-action strategy - which is an essential practice for reflective practitioners who want to develop innovative approaches to both every day and seemingly intractable problems. Although action research can enable change within larger systems, on a smaller scale, individual and firm professional practices can also be improved by undertaking action research. It is an action learning strategy usefully employed regardless of professional role. To illustrate how, even on a small scale, action research can be helpful, I provide examples of how we use this type of research to create local change and systemic responses to challenging human rights and access to justice issues faced in my legal practice sector.

\section{THE PROMISE OF REFLECTIVE PRACTICE}

Although most legal professionals will be unfamiliar with the term "reflective practice," many will recognize that they themselves to some degree are intuitively "reflective practitioners." I discovered the terms "reflective practice" and "reflective inquiry" while researching ways to generate new knowledge, enhance innovative thinking, and support collective learning in my workplace. ${ }^{23}$ My understanding of the powerful role that reflection plays in supporting professional learning and development emerged from theoretical texts and empirical research studies in the fields of higher, adult, management, and professional education. I experienced an epiphany about the potentially transformative nature of emphasizing reflection in legal education and the profession as I delved into the burgeoning literature about reflective practice - a term that originated in 1983 from Donald Schön's groundbreaking research on professional learning. ${ }^{24}$

Reflective practice captured the "lived experience" of my learning journey towards becoming a competent, engaged, and ethical legal professional. However, it was a term I had never heard in the

22 I use the term "access to justice sector" inclusively to capture services offered by Legal Aid Ontario, Ontario's community legal clinics, private bar lawyers on legal aid certificates, court staff, judges, lawyers offering pro bono services, student legal clinics, public legal education organizations, and advocacy organizations, for example.

23 I initially undertook this research during my graduate studies towards a Master of Adult Education. It has since led to my doctoral research on legal education reform and reimagining legal education. My research compares approaches to reflective practice in other disciplines with approaches taken in Canadian and Australian legal education.

24 Donald A Schön, The Reflective Practitioner: How Professionals Think in Action (New York: Basic Books, 1983) [Schön, Reflective Practitioner]. 
course of my legal training. ${ }^{25}$ I uncovered a rich body of reflective practice theory in other professional disciplines that was normative, aspirational, and disruptive (particularly, the capacious literature on critically reflective practice). ${ }^{26}$ Most professional disciplines, including medicine, health, and teaching, recognize reflective practice as a core professional competency, identified as being crucial to professional formation and identity. It is considered essential to developing professionally as it facilitates the transition from student novice to expert professional. It is crucial component of effective professional practice and a harbinger of self-directed lifelong learning, in addition to providing other benefits. $^{27}$

I discovered that reflective practice had not been much theorized in Canadian legal education pedagogy, with the exception of clinical legal education (as it strongly correlates with creating experience-based knowledge). ${ }^{28}$ However, Professor Julie Macfarlane, who began writing about reflective practice as early as 1992, has noted:

Reflective practice, which comprises responsiveness to change, flexibility, and an emphasis on professional self-growth, is increasingly talked about as an appropriate contemporary goal for educators and practitioners alike. A reflective practice model ... focuses on teaching future professionals to analyze and learn from their experiences, emphasizing self-awareness, self-critique and constant analysis and review ... Whereas reflective practice and problem solving require adaptability, flexibility and an openness to change, law school teaches adherence to rules, regulations, and existing legal, pedagogical, and cultural norms. ${ }^{29}$

25 Donald Schön first wrote about reflective practice in 1983, as I explore more briefly in another article. See Leering, "Integrated Reflective Practice," supra note 6 at 9. Since 1983 extensive literature has been produced in all of the professions and in an international journal devoted to reflective practice. See "Reflective Practice: International and Multidisciplinary Perspectives" online: <www.tandfonline.com/loi/crep20>.

26 A summary of the benefits is beyond the scope and intent of this article, but see Michele M. Leering, "Literature Review of Reflection and Reflective Practice across the Professions" (2017) [unpublished, on file with author] [Leering, "Literature Review"]. See also Leering, "Reflective Practice," supra note 6 at 98-99, 102-104.

27 Leering, "Literature Review," ibid, Eg.a recent study of medical students at one American university revealed a significant relationship between lack of reflective ability and professional lapses. See Leslie A Hoffman et al, "Is Reflective Ability Associated with Professionalism Lapses during Medical School” (2016) 91:6 Academic Medicine 853.

28 Clinical legal educators have been "early adopters" of reflective practice. See Sarah Buhler, Sarah Marsden \& Gemma Smyth, Clinical Law: Practice, Theory and Social Justice Advocacy (Toronto: Emond Montgomery, 2016); Donald A Schön, "Educating the Reflective Legal Practitioner" (1995) 2:1 Clinical L Rev 231. "Early adopters" of reflective practice in traditional legal education in the United Kingdom include Julian Webb and Caroline Maughan. See Julian Webb \& Caroline Maughan, eds, Teaching Lawyers' Skills (London: Butterworths, 1996). See also Karen Hinett, Developing Reflective Practice in Legal Education (Warwick: UK Centre for Legal Education, 2002), online: $<$ law2.wlu.edu/deptimages/Externship\%20Program/developingreflectivepractice.pdf>; Leering, "Literature Review," supra note 26.

29 Julie Macfarlane, The New Lawyer: How Settlement Is Transforming the Practice of Law (Vancouver: UBC Press, 2007) at $229-230$. 
Furthermore, building on Macfarlane's work, Wesley Pue and Annie Rochette recommended that law students be introduced to reflective practice during law school. ${ }^{30}$ Subsequently, Rochette, who served multiple terms as president of the Canadian Association of Law Teachers, concluded from her doctoral research into Canadian law teaching and learning that legal educators should become explicit reflective practitioners to improve Canadian legal education. ${ }^{31}$ Reflective practice is understood to be crucial to professional formation in other disciplines, so it is surprising that few Canadian law schools have explicitly introduced reflective practice as a core competency. ${ }^{32}$

To contribute to this lacuna in legal education theory, I have been exploring a theory of reflective practice unique to law, which I summarize briefly in part A. ${ }^{33}$ My intention is to help law students, legal educators, and legal professionals develop their own understanding of reflective practice, specific to their stage of professional development and unique to their role. I caution that my working conceptualization is only the beginning of a conversation about what reflective practice means for legal professionals or what it might offer to law. ${ }^{34}$ In addition to its generic benefits for professional learning and developing professional identity, reflection is an important enabling method for innovation. To

30 Annie Rochette \& Wesley Pue, “'Back to Basics'?: University Legal Education and 21st Century Professionalism” (2001) 20 Windsor YB Access Just 167 at 188 [footnotes omitted].

31 Annie Rochette, "Teaching and Learning in Canadian Legal Education: An Empirical Exploration" (Doctorate of Civil Law, McGill University, 2010) at 296-297 [unpublished], online: <http://digitool.library.mcgill.ca/R/?func=dbinjumpfull\&object_id=103488\&local_base=GEN01-MCG02>, citing the influential work of Greg Light, Roy Cox \& Susanna Calkins, Learning and Teaching in Higher Education: The Reflective Professional (Thousand Oaks, CA: Sage, 2009).

32 At least three law Canadian schools have explicitly endorsed reflective practice in their curricular reforms or graduate level attributes. See Osgoode Hall Law School Curriculum Reform Working Group, "Report on the Reform of the Upper Year JD Curriculum" (February 2011) [on file with author]; Mary J Shariff et al, "Academic Innovation Committee on the Robson Hall JD Curriculum: Consultation Paper" (March 2014) at 58, online:

$<$ law.robsonhall.com/.../Academic_Innovation_Committee_Report_12_March_2014.pdf>; University of Saskatchewan College of Law, online: <https://law.usask.ca/documents/students/jd/DesiredGraduate-Attributes.pdf $>$. Furthermore, two provincial law societies recently required a basic form of reflective practice (self-assessment leading to annual learning contracts) to comply with continuing professional development requirements. See Law Society of Alberta, "CPD: Reflective Practice" (2010), online: < https://www.lawsociety.ab.ca/lawyers-and-students/continuingprofessional-development/background/cpd-reflective-practice/ >; Nova Scotia Barristers' Society, "Assessing your CPD Plan" (2014), online: <http://nsbs.org/assessing-your-cpd-plan>. It is worthy of note that almost all Canadian clinical legal education programs encourage some form of reflective practice and have done so for many year using learning journals, case rounds, and self-directed reflective activities. See Buhler, Marsden \& Smyth, supra note 28.

33 For a more comprehensive look at a working conceptualization for reflective practice, see Leering, "Reflective Practice," supra note 6; Leering, "Integrated Reflective Practice," supra note 6.

34 I have been encouraged to find others more explicitly writing about reflective practice in the context of legal education, legal practice, and dispute resolution in recent years. See Rachael Field \& James Duffy, "Lawyers as Reflective Professionals" in Rachael M Field, James Duffy \& Anna Huggins, eds, Lawyering and Positive Professional Identity (Chatswood, Australia: LexisNexis, 2014) 99; Michelle LeBaron \& Mario Patera, "Reflective Practice in the New Millennium" in Christopher Honeyman, James Coben \& Giuseppe De Palo, eds, Rethinking Negotiation Teaching: Innovations for Context and Culture (Saint Paul, MN: DRI Press, 2009) 45; Kenneth J Fox "Mirror as Prism:

Reimagining Reflexive Dispute Resolution Practice in a Globalized World" (2014) 45 Wash U JL \& Pol'y 41 (reviewing the development of reflective practice and its applicability to his field of practice working in the global dispute resolution environment). See also Timothy Casey, "Reflective Practice in Legal Education: The Stages of Reflection" (2014) 20 Clinical L Rev 317. 
explain its importance, in part B, I provide four examples of its catalytic role in supporting innovative thinking and change. In part C, I then establish how crucial reflection is to shifting "meaning perspectives" (what people value) according to transformative learning theory. Seen in this light, reflection is critical for creating the impetus and the will to act on access to justice issues. Considering the potential positive impact of opportunities to generate transformative learning, in part C, I briefly explain how reflective practice might be more systematically introduced in legal education. I note how students' "access to justice consciousness" could be cultivated by strengthening the reflective component of experiential learning opportunities. Finally, to model critically reflective inquiry, I use reflective questions to challenge our assumptions about legal education and to help envision new futureforming possibilities.

\section{A. Conceptualizing the Reflective Practitioner in Law}

Based on the findings of my preliminary research study, I have conceptualized a reflective practitioner in law as a professional who is self-reflective and self-aware; who critically reflects on practice (what one does), theory (what one knows), and values (what one believes); and who acts to improve practice based on reflective insights (praxis). Reflective practice builds "practical wisdom" (phrónêsis) while providing a space to continually re-examine professional ethical responsibilities. ${ }^{35}$ Reflective practice starts from the premise that professionals integrate theory (knowledge) and practice (skills) to develop professional competence, cultivate a rigorous habit of learning from experience, and continually evaluate and enhance professional expertise. At its most fundamental level, reflective practice requires skills in self-assessment - in the spirit of continually improving practice - to ensure one becomes a more proficient legal professional. However, this is only the beginning; this minimum standard is then enriched by adding critical reflection of all kinds (on assumptions, on practice, on law, on justice, on "law as lived," on what constitutes legal knowledge), and self-reflection. Integrating the insights gained from these reflective domains leads to further insight and richer professional knowledge. The capacity to reflect collectively with peers, colleagues, and others increases the rigour of reflection, interrogates assumptions, and supports learning from others. It also builds the capacity for generative dialogue to create new knowledge and envision new possibilities: this capacity is crucial for tackling access to justice challenges. A final component is "praxis" - making sure one acts on the insights gleaned from reflection.

The complexity and depth of reflective practice varies from what I call its instrumental objective the intent to simply develop professional expertise and "do things better" - to its more transformative objectives. At the transformative end of the spectrum, a critically reflective practice can lead to changing fundamentally what we do, why we do it, and what we believe about our professional role and ethical responsibilities. The transformative potential of reflective practice in law is an intriguing and vast topic

35 Given the paucity of theory about reflective practice applicable specifically to law and to foster dialogue and encourage experimentation with reflective practice techniques, I developed an aspirational working conceptualization of reflective practice unique to law. To do so, I synthesized the results of a cross-disciplinary literature review, interviewed law professors, engaged in observational and documentary research at a law school, engaged in action research, and interrogated my own professional experience as a lawyer, and supervisor of legal professionals. See Leering, "Reflective Practice," supra note 6 at 90-95. 
worthy of further exploration that I cannot do sufficient justice to in this article. In these next subsections, I focus on how reflection supports innovation and critical reflection and, on how it builds the incentive to take action.

\section{B. Linking the Capacity for Reflection to Innovation}

A healthy capacity for reflection underlies the four strategies I discuss below for fostering innovation at the individual, organizational, and system levels. Although it is beyond this article's scope to explore these strategies intensely, they illustrate the impact that a more "reflective muscle" will have on producing a stronger professional culture of reflective inquiry. I analyse and translate ideas from the fields of organizational learning and management education to offer a cross-disciplinary perspective on the transformative and catalytic role that reflection plays in enabling these strategies. I explore: (1) how reflection cultivates innovative thinking; (2) how reflection supports better knowledge management, sharing, and creating of new actionable knowledge; (3) how reflection contributes to organizational learning and building "learning organizations"; and (4) how reflection improves the quality of generative dialogue to contribute and envision new solutions.

\section{Reflection Cultivates Innovative Thinking}

Reflection contributes to innovative thinking in a number of ways. First, reflection provides an opportunity to antidote overlearning, an occupational hazard for professionals that stifles innovative thinking. In his seminal book on reflective practice, Schön noted that a professional's effectiveness can diminish over time and that

[a] practitioner's reflection can serve as a corrective to overlearning. Through reflection, he can surface and criticize the tacit understandings that have grown up around the repetitive experiences of a specialized practice, and can make new sense of the situations or uncertainty or uniqueness which he may allow himself to experience. ${ }^{36}$

Reflection seeds the ground for developing new understandings, thought patterns, and theories of change.

Second, reflection supports "reframing," another concept first advanced by Schön, which provides a fresh look at problematic situations by investigating them from new angles, leading to alternative perspectives on how the problem might be understood. ${ }^{37}$ One must become aware of the tacit understandings one holds about an issue and begin toquestion those assumptions, which should lead to conceiving of new approaches. The research about access to justice and the six principles laid out by the Action Committee provide opportunities to reframe. For example, we can reframe how we think about

36 Schön, Reflective Practitioner, supra note 24 at 61,309-312. This point was picked up by Chris Argyris, cautioning that smart people (like lawyers) often overlearn and that reflection can serve to unsettle or disrupt thought patterns that have become habitual or ingrained leading to a disinclination for change and decreasing professional effectiveness over time. See Chris Argyris, “Teaching Smart People How to Learn” (1991) 69:3 Harv Bus Rev 99.

37 See generally Schön, Reflective Practitioner, supra note 24; J Loughran, "Reflection through Collaborative Action Research and Inquiry" in Nona Lyons, ed, Handbook of Reflection and Reflective Inquiry: Mapping a Way of Knowing for Professional Reflective Inquiry (New York: Springer Science and Business Media, 2010) 399. 
access to justice, the nature of professional obligations, the effective practice of law, benefits of technology, and perceptions of self-represented litigants.

Third, the concepts of "single loop" and "double loop" learning, also originally popularized by Schön and Chris Argyris, help us to understand how to more critically reflect on complex problems. Single loop learning refers to using techniques to solve a problem within existing frameworks of understanding - a kind of trial-and-error type of analysis. Engaging in double loop learning, on the other hand, involves thinking outside existing systems or paradigms to look for new and more innovative solutions. ${ }^{38}$ Learning theorists, such as Joseph Raelin, now identify "triple loop" or "third-order learning" as challenging our entire "assumptive frame of reference" and basic premises. ${ }^{39}$ Clearly, innovative thinking on access to justice challenges could be strengthened by ensuring one engages in double or triple loop learning approaches. (An example of single loop learning is that the solution to the access to justice crisis is more lawyers or paralegals.) Approaches like "social innovation," "design thinking," "collective wisdom," and "collective impact" use reflective processes to encourage these differentiated forms of learning loops and are also deserving of further exploration in law. ${ }^{40}$

\section{Reflection Supports Better Knowledge Management, Sharing, and Creating New Knowledge}

Reflective practice can lead to improved knowledge management $[\mathrm{KM}]$, resulting in cost-saving efficiencies and service improvements and leaner, more effective organizations. ${ }^{41}$ Reducing the cost of legal services helps to remove one of the major impediments to access to justice. A fundamental premise

38 Chris Argyris \& Donald Schön, Theory in Practice: Increasing Professional Effectiveness (San Francisco: Jossey-Bass, 1974).

39 Joseph A Raelin, Work-Based Learning: Bridging Knowledge and Action in the Workplace (San Francisco: Jossey-Bass, 2008) at $15-16$.

40 For a further exploration of social innovation in the context of collaborative law developments, see Martha E Simmons, "Innovative Thinking and Clinical Education: The Experience of the Osgoode Mediation Intensive Program" (2014) 37:1 Man LJ 363. Social innovation is also linked to reflective practice and the capacity for "learning pattern recognition and analysis, understanding system dynamics and complexities, and testing the underlying assumptions of long-established practice." See David S Weiss \& Claude Legrand, Innovative Intelligence: The Art and Practice of Leading Sustainable Innovation in Your Organization (Mississauga: John Wiley \& Sons Canada, 2011) at 7, for innovative thinking described as "the process of solving problems by discovering, combining, and arranging insights, ideas, and methods in new ways." It is contrasted with analytical thinking. The four-step innovative thinking process described is actually a highly reflective action research process (at 68). For an initial introduction to design thinking, see Tim Johnson, "The New Design of Thinking," University Affairs (13 January 2016) at 18-21, online: <www.universityaffairs.ca/features/featurearticle/design-thinking-changing-way-approach-problems/>. For an introduction to design thinking in law, see Margaret Hagan, "Design Thinking and Law: A Perfect Match" (2014) L Prac Today, online:

$<$ www.americanbar.org/content/newsletter/publications/law_practice_today_home/lpt-archives/2014/january14/designthinking-and-law.html>. See also Victor D. Quintanilla, "Human-centered Civil Justice Design" (2017) 121:3 Penn St. L. Rev 745. For an introduction to collective wisdom, see Alan Briskin et al, The Power of Collective Wisdom: And the Trap of Collective Folly (San Francisco: Berrett-Koehler, 2009). For an introduction to collective impact, see Liz Weaver, "The Promise and Peril of Collective Impact" (2014) 26:1 Philanthropist 11.

41 See Michele Leering, "Literature Review" in Michele Leering et al, Knowledge Management, Sharing and Creation: Building on our Strengths and Enhancing Access to Justice (Belleville, Ontario: Provincial Learning Community on Knowledge Management and Transfer, 2010) [unpublished, on file with author]. Included in effective knowledge management are unpacking existing work processes, surfacing the tacit knowledge and assumptions behind these, instigating more efficient work processes, and embedding knowledge into everyday work flows. 
of $\mathrm{KM}$ is that experts often know more than they can communicate readily to others (known as tacit knowledge), but this knowledge can be surfaced through reflection on their practices and what they know so that it can be shared with others. (This realization was the original genesis of Schön's study of how professionals learn.) By developing better KM practices, existing knowledge can be more efficiently reused, and new knowledge can be created more easily. Effective KM is a perennial challenge for law firms and legal organizations seeking to reduce costs. Improved KM practices provide intellectual, collective, and virtual spaces for generating new knowledge and better services more efficiently and rapidly.

Methods that help create new knowledge effectively include "communities of practice" where professionals voluntarily come together to share their knowledge and improve their practices. This approach is exemplified by faculty learning communities aiming to improve pedagogy. It is also a method that at least two law schools - one American and one Australian - have advanced with law students to improve their learning and prepare them for professional practice. ${ }^{42} \mathrm{KM}$ strategies also include the innovative use of technology such as document repositories for best practices, collaboratively created legal research wikis to replace legal memos continually generated from scratch, and other methods to avoid "reinventing the wheel," including new approaches to using artificial intelligence to improve efficiency.

\section{Reflection Contributes to Organizational Learning and Building "Learning Organizations"}

The extensive literature extolling the benefits of organizational learning and the advantages of learning organizations is also relevant to our quest for innovative approaches. The premise is that cultivating learning organizations is critical for thriving in a rapidly changing world. Peter Senge, who popularized the term "learning organization" defined it as a place where people continually expand their capacity to create the results they truly desire, ${ }^{43}$ where new and expansive patterns of thinking are nurtured, where collective aspiration is set free, and where people are continually learning how to learn together. $^{44}$

42 For a general discussion, see Etienne Wenger, Richard McDermott \& William M Snyder, Cultivating Communities of Practice (Boston: Harvard Business School Press, 2002). For faculty learning communities, see Mariela Tovar et al, "Overcoming Pedagogical Solitude: The Transformative Power of Discipline-Specific Faculty Learning Communities (FLCs)" (2015) 34:1-2 To Improve Academy 319. For law students, see Christina D Lockwood, "Improving Learning in the Law School Practice by Encouraging Students to Form Communities of Practice" (2013) 20 Clinical L Rev 95. See also Penelope Watson, "Leading Change in Legal Education: Interesting Ideas for Interesting Times" (2012) Legal Education Rev 9. Later in the article, I provide an example from my own practice.

43 See Peter M Senge, The Fifth Discipline: The Art and Practice of the Learning Organization (New York: Doubleday, 1990). See also William D Hitt, "The Learning Organization: Some Reflections on Organizational Renewal" (1995) 16:8 Leadership \& Organization Development J 17. For a discussion of the importance of critical reflection in developing learning organizations, see Marianne van Woerkom \& Marcel Croon, "Operationalizing Critically Reflective Work Behaviour" (2008) 37:2 Personnel Rev 317. For a most interesting analysis of reconceptualizing law schools as learning organizations and the implications for legal education reform in Australia, see Watson, supra note 42.

44 Senge, ibid at 3. 
The CBA's Reaching Equal Justice Report recommended that the justice system encourage "equal justice by ensuring justice institutions are "learning organizations", committed to evidence-based best practices and ongoing innovation." 45 Additionally, the report noted that

[1] earning organizations develop responsive cultures that maintain knowledge about new processes, understand the outside environment and produce creative solutions using the combined knowledge and skills in the organization. This requires cooperation between individuals and groups, strong communication and a culture of trust. ${ }^{46}$

The success of a learning organization is premised on the reflective capacity of its staff. Reflection is the facilitative agent for each of the five disciplines that characterize a successful learning organization: building shared vision, supporting personal mastery, enacting team learning, unpacking mental models, and engaging in systems thinking. Methods to support reflective inquiry have been developed to antidote "defensive routines" that hold individuals and organizations back from innovating and to overcome '"skilled incompetence' - a marvelous oxymoron ... use[d] to describe most adult learners, who are 'highly skillful at protecting themselves from pain and threat posed by learning situations' but consequently fail to learn how to produce the results they really want." ${ }^{47}$ Senge and others have also noted the importance of tempering advocacy approaches with reflective inquiry so that learning can take place as mental models are challenged, a particularly salient challenge for a legal profession whose default strategy is advocacy. ${ }^{48}$

Systems thinking, the fifth discipline, is also a highly applicable concept for enabling justice system innovation. According to Elaine Dundon, there are three reasons why systems thinking is important for creating a culture of innovation: it helps everyone to see themselves as part of a common purpose, to understand how one change or one decision can impact the larger system, and to see new connections and new opportunities in a bigger frame of reference. ${ }^{49}$ Systems thinking provides the energy and the dynamism required to innovate in the justice system, to "put the public first," to "simplify the justice system," and to "focus on outcomes" rather than the inertia that can characteristically stall positive change.

Project-based learning ${ }^{50}$ and work-based learning ${ }^{51}$ round out the discussion of how reflection contributes to organizational learning and a culture of innovation. Project-based learning is characterized

45 CBA, Equal Justice, supra note 2 at 61.

46 Ibid at 88 [citations omitted].

47 Senge, supra note 43 at 182. For more examples of methods, see Senge et al, The Fifth Discipline Fieldbook: Strategies and Tools for Building Learning Organizations (New York: DoubleDay, 1994).

48 For a discussion of the need to balance advocacy and inquiry, see Senge, supra note 43 at 198-199. For additional discussion, see Rick Ross \& Charlotte Roberts, "Balancing Inquiry and Advocacy" in Peter M Senge et al, ibid at 253.

49 Elaine Dundon, The Seeds of Innovation: Cultivating the Synergy That Fosters New Ideas (New York: American Management Association, 2002) at 71. For another look at systems thinking, see Robert Louis Flood, "The Relationship of Systems Thinking to Action Research" in Peter Reason \& Hilary Bradbury, eds, Handbook of Action Research:

Participative Inquiry and Practice (Thousand Oaks, CA: Sage, 2001) 133.

50 For a discussion of the role of reflection in project-based learning, see Andrew J Sense, "An Architecture for Learning in Projects?” (2004) 16:3 J Workplace Learning 123. See also Karen Ayas \& Nick Zeniuk, "Project-based Learning: 
by systematic and collective reflection, sometimes described as action learning (a component of action research), and it works best when difficulties within a particular project are seen as opportunities to learn. Participants must feel comfortable learning without fearing failure and be able to raise difficult issues without feeling defensive. Project-based learning builds communities of reflective practitioners. Reflection is critical to the cycles of planning, doing, observing, and evaluating that characterize effective and collaborative work-based learning. ${ }^{52}$ Reflection should be a visible practice within organizations and built into the way an organization functions. ${ }^{53}$

\section{Reflection Improves the Quality of Generative Dialogue}

The disciplined practice of reflection can improve our capacity to engage in reflective and generative dialogue, in preference to the downloading and debate that so often characterize legal culture and thereby limit our effectiveness as communicators. Adam Kahane and Otto Scharmer have outlined four fields of conversation that differ significantly in their capacity to nurture true dialogue and to generate new ideas. ${ }^{54}$ Downloading is described as "talking nice" - being polite but cautious and not speaking your mind, leading to re-enacting habitual patterns. Debate is advancing one's own point of view through "talking tough" and arguing. (Arguably debate functions as a default strategy for the legal profession.) Reflective dialogue requires active listening in a spirit of inquiry. Generative dialogue, the most aspirational form of communication, requires the parties to converse together in new ways to create a future based on emerging collective insights - being fully present to one another and to new possibilities. Theory U, Appreciative Inquiry, Scenario Planning, and Open Space Technology, to name a few approaches, use reflection to create a positive "future-forming" orientation to lead to paradigmatic shifts in thinking and professional consciousness. These approaches build stronger foresight and a greater capacity to envision new and promising futures. ${ }^{55}$ Improving the quality of dialogue between

Building Communities of Reflective Practitioners" in Christopher Grey \& Elena Antonacopoulou, eds, Essential Readings in Management Learning (Thousand Oaks, CA: Sage, 2004) 271.

51 Raelin, supra note 39.

52 Ibid; Thomas Schley \& Marianne van Woerkom, "Reflection and Reflective Behaviour in Work Teams" in Christian Harteis, Andreas Rausch \& Jürgen Seifried, eds, Discourses on Professional Learning: On the Boundary between Learning and Working, Professional and Practice-based Learning (New York: Springer Science and Business Media, 2014) 113. See also Fred AJ Korthagen, "The Organization in Balance: Reflection and Intuition as Complementary Processes" (2005) 36:3 Management Learning 371.

53 Kati Tikkamäki \& Sanna Hilden, "Making Work More Visible by Reflective Practice" (2014) 19:3 Research in PostCompulsory Education 287. We have embedded reflective practices systematically in our community legal clinic work , including articulating reflective practice competencies applicable to all staff categories.

54 C Otto Scharmer, Theory U: Leading from the Future as it Emerges (Cambridge, MA: Society for Organizational Learning, 2007); Adam Kahane, "Changing the World by How We Talk and Listen" (2002) 26:1 Leader to Leader 1. For a related discussion, see Claus D Jacobs \& Loizos Th Heracleous, "Answers for Questions to Come: Reflective Dialogue as an Enabler of Strategic Innovation” (2005) 18:4 J Organizational Change Management 337.

55 Research with a future-forming orientation is described as "reflective pragmatism" by Kenneth J Gergen. See Kenneth J Gergen, "From Mirroring to World-Making: Research as Future Forming" (2015) 45:3 J Theory Social Behaviour 287. For information on Theory U, see Scharmer, ibid. For a summary of the other future-forming technologies listed, see Peggy Holman, Tom Devane \& Steve Cady, eds, The Change Handbook: The Definitive Resource on Today's Best Methods for Engaging Whole Systems (San Francisco: Berrett-Koehler, 2007). 
legal professionals can only help to support a culture of reform and to enact the national Action Committee's recommended principles to "collaborate and coordinate" and "focus on outcomes."

Having reviewed how reflection enables four strategies that encourage innovation, I now discuss how becoming more adept at encouraging reflection - borrowing from transformative learning theory - can help shift perspectives and engage the will to act on access to justice.

\section{Reflection Enables Transformative Learning and Builds the Will to Act}

During a recent lecture exploring the legal profession's responsibility to ensure equal access to justice, Justice Thomas Cromwell as he then was, chair of the Action Committee, mused about the challenges of creating the will to act in the legal profession and how the profession could be persuaded to embrace a stronger leadership role as a catalyst for reform. ${ }^{56}$ Quoting his son's soccer coach, he observed simply that "you've got to want it." According to transformative learning theory, exposing law students and legal professionals to disorienting information about the lack of equal justice in Canada, coupled with creating the space for critically reflective questions to be asked, could also help activate an "access to justice consciousness" and the will to act. Transformative learning theory and facilitated reflection provide hope that change in attitudes and values is possible. ${ }^{57}$

Transformative learning occurs when learners are exposed to disorienting information that they cannot reconcile with their prior experiences or beliefs. Although it is beyond the scope of this article to outline the complexities of transformative learning theory ${ }^{58}$ shifts in "meaning perspective" can result from reflecting after exposure to disorienting information. In the case of the legal profession, information about growing justice gaps, situations of injustice, how the "law is lived," or even negative feedback on how one's clients or the public perceive legal services can be disconcerting. ${ }^{59}$ This discomforting information can disrupt one's assumptions, for example, about how the law actually works in everyday life or whether the justice system and the legal profession do provide meaningful access to justice for many members of the public who need it. ${ }^{60}$ As a result of reflecting on the

56 Justice Thomas Cromwell, The Legal Services Gap: Professional Responsibility and Access to Justice (McCarthyTetrault Annual Lecture, Faculty of Law, Queen's University, Kingston, ON, 2016).

57 For a discussion of how transformative learning theory has been discussed in law, some of the challenges that can be presented and what to do about it, see Jane H Aiken, "Striving to Teach Justice, Fairness, and Morality" (1997) 4 Clinical L Rev 1; Fran Quigley, "Seizing the Disorienting Moment" (1995) 2 Clinical L Rev 37.

58 Transformative learning - leading to a shift in meaning perspectives, attitudes, and beliefs - has been proven to result from "disorienting dilemma" and difficult situations or information that challenge our assumptions. Transformative learning theory is attributed to Jack Mezirow and has been extensively discussed and documented. See Jack Mezirow, "How Critical Reflection Triggers Transformative Learning" in Jack Mezirow and Associates, Fostering Critical Reflection in Adulthood: A Guide to Transformative and Emancipatory Learning (San Francisco: Jossey-Bass, 1990) 159.

59 All legal professionals can consider the impact of their professional services - whether the recipient of those services is a law student in the case of a legal educator, a client in the case of a licensed member of the legal profession, or a member of the general public with a simmering legal problem who is seeking legal help (or not).

60 A reading of the national reports will provide disorienting information. The Equal Justice report summarizes a great deal of the empirical research on access to justice and legal needs. See CBA, Equal Justice, supra note 2. For a larger perspective on rethinking the nature of legal services, particularly for low income or vulnerable populations, see Pleasance et al, Reshaping Legal Assistance, supra note 18. A day spent at court with unrepresented litigants can do the same, as can experience in clinical legal education programs. 
"disorienting dilemma" (as it is termed by Jack Mezirow), a new meaning perspective could emerge with implications for an enhanced sense of legal professionalism and responsibility. This critical reflection may also provide an opportunity for professional rejuvenation. Many legal professionals face a crisis of meaning and purpose, evidenced by the growing concerns of Canadian lawyer organizations and empirical studies that establish that the mental health and well-being of both law students and lawyers is being negatively impacted. ${ }^{61}$ This crisis offers an opportunity for legal professionals to rededicate themselves to the justice ideals that brought many of them to law school in the first place, to articulate their theory of professional practice, and to explore values-based lawyering.

Having now reviewed how reflection supports innovation and how it can be constructively used to support transformative learning, I conclude this section with a brief discussion about reflective practice as a pedagogical innovation in legal education and opportunities for transformative learning.

\section{Introducing Reflective Practice into Legal Education: A Pedagogical Innovation}

How can we make building a reflective muscle or orientation a more explicit goal in legal education? I explored some possibilities for systematically introducing reflective practice as a pedagogical innovation at law school in a recent article in the Canadian Bar Review. ${ }^{62}$ Building on that preliminary exploration, in this article I consider the potential for reflective approaches to engage law students more deeply in equal justice issues.

To encourage students to be critically reflective about access to justice and to stimulate innovative thinking, many Canadian law schools are introducing a more adventurous experiential learning curriculum on access to justice issues, including service learning. ${ }^{63}$ Experiential learning benefits from a

61 See Homewood Health, "Member Assistance Program," online: <myassistplan.com/>; CBA, "Wellness Programs" (2016), online: <www.cba.org/CBA-Wellness/Wellness-Programs>. See also Patrick J Schlitz, "On Being a Happy, Healthy, and Ethical Member of an Unhappy, Unhealthy, and Unethical Profession" (1999) 54:2 Vanderbilt LR 871; John Sonsteng et al, "A Legal Education Renaissance: A Practical Approach for the Twenty-First Century" (2007) 34:1 Wm Mitchell LR 303; Roy Stuckey et al, Best Practices for Legal Education: A Vision and a Road Map (New York: Clinical Legal Education Association, 2007); Lawrence Krieger, "What We're Not Telling Law Students - and Lawyers - That They Really Need to Know: Some Thoughts-In-Action toward Revitalizing the Profession from Its Roots" (1998) 13:1 JL \& Health 1; Lawrence Krieger, "The Inseparability of Professionalism and Personal Satisfaction: Perspectives on Values, Integrity and Happiness" (2004) 11:2 Clinical L Rev 425; KM Sheldon \& Lawrence Krieger, "Understanding the Negative Effects of Legal Education on Law Students: A Longitudinal Text of Self-Determination Theory" (2007) 33:6 Personality \& Social Psychology Bulletin 883; Mary E Pritchard \& Daniel N McIntosh, "What Predicts Adjustment among Law Students? A Longitudinal Panel Study" (2003) 143:6 J Social Psychology 727. For Australian research, see Molly Townes O'Brien, Stephen Tang \& Kath Hall, "Changing our Thinking: Empirical Research on Law Student Wellbeing, Thinking Styles and the Law Curriculum" (2011) 21:2 Legal Educ Rev 149, citing Norm Kelk et al, Courting the Blues: Attitudes towards Depression in Australian Law Students and Legal Practitioners (Camperdown, Australia: Brain and Mind Research Institute, 2009) 42. For Canadian research, see KF Helmers et al, "Stress and Depressed Mood in Medical Students, Law Students, and Graduate Students at McGill University" (1997) 72:8 Academic Medicine 708.

62 See the discussion of how reflective practice might be introduced in the traditional law school curriculum in Leering, "Integrated Reflective Practice," supra note 6.

63 Many Canadian law schools are experimenting with access to justice course innovations. Innovations at several law schools were the subject of "Teaching for Access to Justice" (Workshop delivered at the Canadian Association of Law Teachers 2016 Annual Conference, Faculty of Law, University of Calgary, 30-31 May 2016). See also Jean Sorensen, "Your Courtroom Is Ready!" Canadian Lawyer Magazine (6 June 2016), online: <www.canadianlawyermag.com/60- 
strong reflective component to increase its impact and to enhance learning from experience. Encouraging students to engage in research projects to increase access to justice, including crossdisciplinary projects or community-based action research projects, ${ }^{64}$ will seed the ground for reflecting and innovating in their future practice. Examples of other reflective activities that would help develop an access to justice consciousness include providing mentorship opportunities; developing a model law student code of conduct, ${ }^{65}$ which includes a commitment to fostering access to justice; designing innovative consciousness-raising activities; and providing more experiential learning opportunities through new clinical and externship opportunities. Reflective learning portfolios are a promising capstone activity for these experiences and could include reflective exercises such as drafting an aspirational statement about one's "philosophy of practice" based on reviewing theories of lawyering and alternative paradigms of practice literature or through conducting interviews with legal professionals. $^{66}$

Building the capacity for disciplined and rigorous reflection in the profession, beginning from the first day of law school, will serve as an important enabler of innovation in the justice sector. Nurturing reflection and the capacity for reflective practice may seem like an insurmountable challenge in a law school curriculum that has been dominated by a concern for teaching students to "think like a lawyer"67

50/Your-courtroom-is-ready.html>. The CBA's Access to Justice Committee, of which I have been a member, is developing a guide to experiential learning in collaboration with interested Canadian legal educators that will contain a robust reflective component and endorse reflective practice.

64 For law school examples, see Emily MS Houh \& Kristin Kalsen, "It's Critical: Legal Participatory Action Research" (2014) 19 Mich J Race \& L 287; Christopher Bacon et al, "Introduction to Empowered Partnerships: Community-Based Participatory Action Research for Environmental Justice" (2013) 6:1 Environmental Justice 1; Susan R Jones \& Shirley J Jones, "Innovative Approaches to Public Service through Institutionalized Action Research: Reflections from Law \& Social Work" (2011) 33:4 UALR L 377. See also Lisa Turik, Michele Leering \& Danielle Holbrough, "Justice and Health Partnership Project Interim Report" (January 2016), online: Community Advocacy \& Legal Centre $<$ http://communitylegalcentre.ca/JHP/resources/Docs/JHP-Interim-Report-2016.pdf $>$.

65 David M Tanovich, "Thinking Like a Lawyer: A Model Code of Professional Responsibility for Law Students" (2009) 27:1 Windsor YB Access Just 75. An experiential learning guide for Canadian law students is also under development by the CBA, supra, note 63 .

66 Learning portfolios are strongly encouraged in many other professions, particularly medicine, and are being implemented in some Australian law schools. See Leering, "Integrated Reflective Practice," supra note 6 at 37-38. Encouraging students to draft a philosophy of professional practice as a capstone experience could help to articulate their ethical and professional commitments and help to bridge the transition from law school to practice. Reflection on professional identity in final year transitional options is discussed in Susan Armstrong \& Judith McNamara, "Transition Pedagogy in First and Final Year Law Programs" in Sally Kift et al, Excellence and Innovation in Legal Education (Chatswood, Australia: LexisNexis Butterworths, 2011). Neil W Hamilton, "Formation-of-an-Ethical-Professional-Identity (Professionalism) Learning Outcomes And E-Portfolio Formative Assessments 48 (2017) University of the Pacific Law Review 847.

67 The Carnegie Foundation study describes "thinking like a lawyer," with the primary form of teaching being the case dialogue method, as a signature pedagogy of legal education. Thinking like a lawyer is defined as the capacity to understand "legal processes, seeing both sides of legal arguments, for sifting through facts and precedents in search of the more plausible account, for using precise language, and of understanding the applications and conflict of legal rules." William M Sullivan et al, Educating Lawyers: Preparation for the Profession of Law (Stanford: Carnegie Foundation for the Advancement of Teaching, 2007) at 186. For interesting interrogation of "thinking like a lawyer," see Rebecca Huxley-Binns, "Tripping over Thresholds: A Reflection on Legal Andragogy" (2016) 50:1 Law Teacher 1; Paul 
and within a legal education and university system that seems intransigent. Consider the following reflective questions as part of a "thought experiment"68 - an experiment in this context intended to encourage creative and "outside-the-box" thinking. Should we critically reflect on the prevailing mantra that law school teaches students to "think like lawyers"? Does the heuristic "thinking like a lawyer" constrain our imagination? Given what we are now learning about what it takes to become an effective and innovative legal professional, it seems likely that law students must now actually think much more imaginatively than the phrase "thinking like a lawyer" has traditionally required, and that reflection is a crucial aspect of this "competency."

How we frame "thinking like a lawyer" has enormous consequences for how we organize legal education and develop appropriate curriculum. Is it possible that we are failing to nurture other valuable professional competencies, including reflection, as a result of being stuck in an antiquated mental model of what "thinking like a lawyer" entails? Does the continued use of the metaphor that law students enter law school as "blank slates" derogate from the special capacities and competencies these students bring from other disciplines? Would a greater appreciation of the gifts they bring from their life prior to law school help stimulate their creative and innovative thinking about law, legal practice, professionalism, and how to ensure access to justice? If we intend to foster innovative thinking about law, how to practice, or how to innovate more systematically, do we need to reframe what it means think like a lawyer? Law schools' rich tradition of encouraging critical thinking through jurisprudential, legal realism, critical legal theory, and "law and," 69 as well as perspective courses, as examples, provide a strong catalyst for a more reflective critique of legal institutions as well as "law as lived." 70 How can we build on this proud intellectual history to increase students' capacity to reflect critically on access to justice in ways that lead to action and impact how they might practise law?

Another possible thought experiment relates to issues raised by the national reports on access to justice and the Futures report about new legal professional roles. ${ }^{71}$ What if "zealous advocacy" and the "hired gun" role were not the dominant ethos and professional paradigm for legal practice? What if legal professionals were seen as healers or helpers, or problem-solvers as some influential thinkers have already advocated $?^{72}$ What would be the implications? This prevalent ethos has implicitly, and often

Maharg, Transforming Legal Education: Learning and Teaching Law in the Early Twenty-first Century (Burlington, VT: Ashgate, 2007) at 272.

68 A thought experiment in this context is a term attributed to Einstein but used here in the context of encouraging innovative or creative thinking. For this usage, see, eg, Giovanni Emanuele Corazza \& Sergio Agnoli, eds, Multidisciplinary Contributions to the Science of Creative Thinking (New York: Springer, 2016).

69 Referring to, eg, law and literature, law and politics, law and economics.

70 This phrase is often attributed to Roderick A Macdonald. See Des Rosiers, supra note 10.

71 CBA, Futures, supra note 3. Exploring the different vectors of legal practice, see Susan Daicoff, "Law as a Healing Profession: The "Comprehensive Law Movement" (2006) 6:1 Pepp Disp Resol LJ 1 [Daicoff, "Healing Profession"]. For an assessment exercise to assist with developing a philosophy of practice, see ibid. See also Christine Parker \& Adrian Evans, Inside Lawyers Ethics, 2d ed (New York: Cambridge University Press, 2014); CBA, Do Law Differently: Futures for Young Lawyers (Ottawa: CBA, 2016) [CBA, Do Law Differently]; Richard E Susskind, The End of Lawyers?: Rethinking the Nature of Legal Issues (New York: Oxford University Press, 2008).

72 David Mullan discussed lawyers as healers during his Spring Convocation 2015 speech. David Mullan (Lecture presented at the 2015 Convocation, Faculty of Law, Queen's University, Kingston, ON, 2015). See also Former Chief Justice Roy McMurtry quoted in Lorne Sossin, "The Helping Profession: Can Pro Bono Lawyers Make Sick People 
explicitly, devalued other professional approaches to solving problems or transforming conflict. The desired culture of reform in the justice sector is best supported by developing capacities like reflective inquiry, creative and holistic problem solving, emotional and social intelligence, multi-disciplinary collaboration, and conflict transformation, all of which have been traditionally undervalued in the legal curriculum of most law schools, except in clinical legal education and mediation courses.

There is a wealth of opportunities for envisioning different futures for legal professionals, as is exemplified by growing worldwide "comprehensive law" and "integrative law" movements. Examining these movements provides much reflective fodder for student inspiration. ${ }^{74}$ According to Susan Daicoff, examples of new vectors for legal professional practice include therapeutic jurisprudence, preventative law, creative problem solving, holistic justice, collaborative law, transformative mediation, restorative justice, and problem-solving courts. ${ }^{75}$ Using thought experiments to challenge prevalent mental models about the legal profession and the now impoverished "thinking like a lawyer" mantra can stimulate thinking about new paradigms of legal practice that could better meet the needs of the public. ${ }^{76}$ The CBA's reports document the need for new forms of professional expertise to respond to the growing justice gap. ${ }^{77}$ Creating and sustaining a vibrant discourse about new paradigms of legal practice could be an important catalyst for law students becoming more innovative in the future and encouraging them to practise law differently.

In summary, in this section, I have explored how introducing reflective practice as a professional competency, beginning in law school, could build a stronger "reflexive muscle," support greater innovative thinking, create new knowledge through more robust knowledge management, foster organizational learning and build learning organizations, and improve the generative quality of dialogue

Well" in Adam Dodek \& Alice Wooley, eds, In Search of the Ethical Lawyer: Stories from the Canadian Legal Profession (Vancouver: UBC Press, 2016) 150 at 162.

73 See J Kim Wright, Lawyers as Changemakers: The Global Integrative Law Movement (Chicago: ABA Book Publishing, 2016) [Wright, Changemakers]; J Kim Wright, Lawyers as Peacemakers: Practicing Holistic, Problem-Solving Law (Chicago: ABA Publishing, 2010) [Wright, Peacemakers]. See also Marjorie Silver, Transforming Justice: Lawyers and the Practice of Law (Durham, NC: Carolina Academic Press, 2017); Susan Swaim Daicoff, Comprehensive Law Practice: Law as a Healing Profession (Durham, NC: Carolina Academic Press, 2011) [Daicoff, Comprehensive Law Practice].

74 See Daicoff, "Healing Profession," supra note 71; Wright, Peacemakers, ibid; Wright, Changemakers, ibid. This was also the subject of a recent workshop (Developing a Philosophy of Professional Practice and Emerging Alternative Forms of Practice, IJCLE \& ACCLE Annual Conference, Faculty of Law, University of Toronto, 10-12 July 2016).

75 Daicoff, "Healing Profession," supra note 71 at 49-52.

76 Daicoff, Comprehensive Law Practice, supra note 73. For additional discussions about theories of practice, see Susan L Brooks, "Using a Communication Perspective to Teach Relational Lawyering" (2015) 15:2 Nev LJ 477; Michael Diamond, "Community Lawyering: Revisiting the Old Neighbourhood" (2000) 32:1 Colum Hum Rts L Rev 67; Gerald P López, Rebellious Lawyering: One Chicano's Vision of Progressive Law Practice (Boulder: Westview Press, 1992); Amanda Dodge, "Emancipatory Lawyering: Visions of Advocacy and Solidarity with Marginalized Communities in Saskatchewan" (2015) [unpublished, on file with author]. See also Susan G Kupfer, "Authentic Legal Practices" (1996) 10:1 Geo J Legal Ethics 33; Deborah J Cantrell, "Can Compassionate Practice Also Be Good Legal Practice: Answers from the Lives of Buddhist Lawyers" (2010) 12:1 Rutgers JL \& Religion 3; Austin Sarat \& Stuart A Scheingold, The Worlds Cause Lawyers Make: Structure and Agency in Legal Practice (Stanford: Stanford University Press, 2005); Macfarlane, supra note 29.

77 See CBA, Futures, supra note 3; CBA, Do Law Differently, supra note 71. 
in the profession. I have shared insights from transformative learning theory to examine how encouraging reflection after experiencing disorienting dilemmas could help to cultivate an access to justice consciousness and embolden the will to act. I concluded this section by introducing thought experiments to reflect on current legal education and legal practice paradigms, to illustrate how bringing a critically reflective perspective can lead to innovative thinking. In this next section, I discuss action research as an enabler of innovation at an individual, organizational, and systems level. Action research links reflection and action and acts as a form of "praxis." It holds much promise for fostering professional and organizational learning and for encouraging systems thinking. ${ }^{78}$ Action research includes a substantial reflective component that makes it an ideal research strategy for reflective practitioners to adopt and also functions as a method for cultivating reflective practice.

\section{ACTION RESEARCH AS AN ENABLER OF INNOVATION}

In this section, I briefly introduce action research to provoke interest in exploring it further and to create a shared vocabulary for dialogue about its potential in law. I set out the typical steps for a smallscale action research project to demonstrate how it works in practice. For those most interested in how action research works on justice-related issues, I then describe examples from my legal practice sector to show what possibilities can be opened up through this research-in-action orientation. I conclude with general remarks about action research, innovation, and how important it is for access to justice innovation to share and mobilize emerging knowledge.

\section{A. Defining Action Research}

Action research is a form of research that is used when there is a desire to improve practice and/or to create change with organizations or systems. ${ }^{79}$ Using largely qualitative data collection methods, it is well suited to situations where little is understood about the problem or the lived experience. Action researchers are usually trying to solve a practical problem rather than studying a phenomenon in the abstract, as is the case when more conventional quantitative and qualitative research methodologies are employed. Largely described as an inductive research strategy, action research is used to develop knowledge and theory while simultaneously supporting change. It results in a richer, deeper, and more multifaceted understanding of the issue being examined by the research, creating situated knowledge about the challenge being faced. It is ideally suited for supporting innovation in the access to justice sector because it encourages reflection and action in a cyclical process that incrementally and iteratively begins to change the situation while it is being researched. This characteristic of action research - that solutions are implemented as the research proceeds - helps to overcome the challenge of getting started on complex problems that initially seem insurmountable. Some forms of action research, such as

78 Flood, supra note 49.

79 Sharan B Merriam \& Edwin L Simpson, A Guide to Research for Educators and Trainers of Adults (Malabar, FL: Krieger, 2000). See also discussion of action research in Michael Quinn Patton, Qualitative Research and Evaluation Methods, 4th ed (Thousand Oaks, CA: Sage, 2015); Stephen Kemmis \& Robin McTaggart, "Participatory Action Research: Communicative Action and the Public Sphere" in Norman K Denzin \& Yvona S Lincoln, eds, The SAGE Handbook of Qualitative Research, 3d ed (London: Sage, 2005) 271. 
participatory action research, pay special attention to incorporating the interests and perspectives of stakeholders concerned about the issue throughout the research, including the people it intends to benefit.

Kurt Lewin is most often credited with developing action research as a methodology. ${ }^{80}$ According to Bridget Somekh and Ken Zeichner,

[h] is vision of action research was as an alternative to the norms of decontextualized research; instead of focusing on surveys and statistical methods, action research's purpose was to improve social formations by involving participants in a cyclical process of fact finding, planning, exploratory action and evaluation. ${ }^{81}$

It has been well utilized for larger-scale projects in human services, health care, business, and in community, organizational, and international development, as a survey of the vast literature will reveal. $^{82}$ Action research has emerged as an important research methodology for dealing with multifaceted complex or "wicked problems." adaptable in many contexts: they have also been used extensively for professional development, particularly by educators. 84

Action research is an umbrella term for a wide variety of action research, action learning, and action science approaches, an exploration of which is beyond the scope of this article. John Creswell has differentiated between practical action research, which aims to improve some aspect of practice, and participatory action research, which has more emancipatory objectives, intending more radical changes and empowerment of the stakeholders. ${ }^{85}$ Depending on the change that one seeks to create, both of these forms of action research, or a cross-over between the two, have much potential to offer to innovation in the justice sector. Ostensibly, there are twenty-seven flavours of action research, ${ }^{86}$ including

80 Kurt Lewin, "Action Research and Minority Problems" (1946) 2:4 Journal of Social Issues 34.

81 Bridget Somekh \& Ken Zeichner, "Action Research for Educational Reform: Remodelling Action Research Theories and Practices in Local Contexts" (2009) 17:1 Educational Action Research 5 at 7.

82 See eg, Peter Reason \& Hilary Bradbury, eds, The SAGE Handbook of Action Research: Participatory Inquiry and Practice, 2d ed (Los Angeles: Sage, 2008); E Alana James, Tracesea Slater \& Alan Buckman, Action Research for Business, Nonprofit, and Public Administration (Thousand Oaks, CA: Sage, 2012); Rowan Popplewell \& Rachel Hayman, "Where, How and Why Are Action Research Approaches Used by International Development NonGovernmental Organizations" (2012), online: <www.intrac.org/data/files/resources/752/Briefing-Paper-32-Where-howand-why-are-Action-Research-approaches-used-by-international-development-non-governmental-organisations.pdf $>$; Michael J Marquardt et al, Action Learning for Developing Leaders and Organisations: Principles, Strategies, and Cases (Washington, DC: American Psychological Association, 2009).

83 See CBA, Equal Justice, supra note 2 and accompanying text.

84 For a good overview of how action research has been used in education, see John W Creswell, Education Research: Planning, Conducting, Evaluating Quantitative and Qualitative Research (Upper Saddle, NJ: Pearson Education, 2008); James H McMillan \& Sally Schumacher, Research in Education: Evidence-based Inquiry 7th ed (Upper Saddle, NJ: Pearson Education, 2010) at 443-453.

85 For a robust discussion of the difference between practical and participatory action research, see McMillan \& Schumacher, supra note 84 at 599-605.

86 Dawn Chandler \& William R Torbert, "Transforming Inquiry and Action: Interweaving 27 Flavors of Action Research" (2003) 1:2 Action Research 133. There have been four generations of action research according to Stephen Kemmis \& 
collaborative inquiry, participatory action research, participatory action learning and action research, ${ }^{87}$ critical action research, systemic action research, ${ }^{88}$ and Appreciative Inquiry (AI). AI is considered the most generative form of action research because it does not focus on deficits and problems but, rather, on opportunities. It gains its strength from an affirmative and strength-based approach and through cultivating an appreciative mindset. ${ }^{89}$ It emphasizes developing positive energy by exploring what already works well and building on this. AI is worth investigating further as an enabler of change because it is a welcome antidote to a legal culture that can be unduly negative and pessimistic.

Stephen Kemmis believes that action research can be transformative and can be used to energize communities of all kinds through changed relationships:

Action research also aims to bring about changes in how people relate to one another in the practice in which they act and interact ... Action research aims to explore new ways of doing things, new ways of thinking, new ways of relating to one another and to the world in the interest of finding those new ways that are more likely to be for the good of each person and the good of humankind, and more likely to help us live sustainably ... To find out what needs to be done differently, we need action research - action research that will inform our individual praxis and inform our collective praxis. $^{90}$

All forms of action research can be characterized as disruptive. David Coghlan noted that action research examines everything, stresses listening, encourages questioning, requires reflection, builds courage, and leads to action. ${ }^{91}$ Morten Levin and Davydd Greenwood asserted that

[a]ction research embodies the principles of pragmatism applied to research and social change. It is knowledge creation, reflection and application in action. It is a quintessentially scientific activity because we test the validity of our understandings in action. On the surface of it, then, action research should be the dominant form of social science inquiry at colleges and universities and in governmental agencies, at least all of those that claim to create knowledge relevant to improving our societies ... Society at large requires approaches to knowledge creation and application to help organizations

Robin McTaggart, "Participatory Action Research: Communicative Action and the Public Sphere" in Norman K Denzin \& Yvona S Lincoln, eds, The SAGE Handbook of Qualitative Research, 3d ed (London: Sage, 2005) 271 at 272-273. Orteun Zuber-Skerritt, Action Leadership: Towards a Participatory Paradigm (New York: Springer, 2011).

88 Danny Burns, "Systemic Action Research: Changing System Dynamics to Support Sustainable Change" 12:1 Action Research 3.

89 See DL Cooperrider, "Positive Image, Positive Action: The Affirmative Basis of Organizing" in S Srivastva \& D L Copperrider, eds, Appreciative Management and Leadership: The Power of Positive Thought and Action in Organizations (San Francisco: Jossey-Bass Publishers, 1999) 91.

90 Stephen Kemmis. "What Is to Be Done? The Place of Action Research: Educational Action Research" (2010) 18:4 Educational Action Research 417 at 424-425 [emphasis in original].

91 David Coghlan, "Insider Action Research Projects: Implications for Practicing Managers" (2001) 32:1 Management Learning 49 at 52 . 
become environments for continuous learning and ongoing adaptation to highly dynamic political, economic and social conditions. ${ }^{92}$

Action research has not had a high profile within legal scholarship, although there are some emerging exceptions that are worthy of closer review, including action research to improve legal education. ${ }^{93} \mathrm{~A}$ consequence of this lack of profile has been that it is under-theorized and under-utilized as a strategy for creating change in professional practice, whether that is in law schools, law firms, or the justice system. ${ }^{94}$ Most legal professionals have never heard of action research, unless they have studied in other disciplines or worked in other sectors. Once understood, the benefits it offers for improving practice, encouraging innovation, and building leadership capacity will become apparent. ${ }^{95}$ Action research projects provide a crucible for experimentation and innovation. It qualifies as a method of systematic reflective practice for practitioners, although it is much more broadly considered in the literature. ${ }^{96}$

Most importantly, undertaking action research does not necessarily require specialized expertise, which makes it very accessible to legal professionals. As explored more fully in the next subsection, it is a participatory and emergent form of inquiry. After posing a problem, a spiralling series of research steps leads to greater understanding and to supporting change. The traditionally articulated steps follow a cyclical process of planning, acting, observing, and evaluating. ${ }^{97}$ Through this cyclical and repeated process of reflection and action, understanding about a problem emerges, a theory about how to improve the situation begins to crystallize, a strategy is developed and implemented to solve the problem, and data is collected to evaluate whether the problem is being solved or the new approach is successful. This process of action reflection usually continues beyond just one action research cycle. Unlike traditional

92 Morten Levin \& Davydd J Greenwood, "Pragmatic Action Research and the Struggle to Transform Universities into Learning Communities" in Peter Reason \& Hilary Bradbury, eds, Handbook of Action Research: Participative Inquiry and Practice (Thousand Oaks, CA: Sage, 2001) 103 at 112.

93 This is beginning to change. See Emily MS Houh \& Kristin Kalsen, "It's Critical: Legal Participatory Action Research" (2014) 19 Mich J Race \& L 287; Christopher Bacon et al, "Introduction to Empowered Partnerships: Community-Based Participatory Action Research for Environmental Justice” (2013) 6:1 Environmental Justice 1; Susan R Jones \& Shirley J Jones, "Innovative Approaches to Public Service Through Institutionalized Action Research: Reflections from Law \& Social Work" (2011) 33:4 U Arkansas at Little Rock L 377. For a discussion of action research in Australian legal education, see Jacqueline Mowbray, "The Post-Graduate Capstone Experience: Negotiating the Pedagogical Tensions" (2015) 8:2 J Learning Design 43 (action research project to create a new capstone course, useful for its case study methodology). See also Patricia Easteal, "The Legal Education Academic: Research-Led Teaching” in Kift et al, supra note 66.

94 However, see this example of the American Centre for Court Innovation as an organization that chose action research as a methodology to help to improve the performance of their drug courts. Michael Rempel, Action Research: Using Information to Improve Your Drug Court (New York: Center for Court Innovation, 2010) online:

$<$ www.courtinnovation.org/sites/default/files/documents/ActionResearch.pdf $>$.

95 For a discussion of an empirical study into the effectiveness of action learning for developing leadership capability, see Marquardt et al, supra note 82 at 222- 225.

96 To apply it to professional projects, see David Coghlan \& Teresa Brannick, Doing Action Research in Your Own Organization, 2d ed (Thousand Oaks, CA: Sage, 2005). For a straightforward guide for action research in small organizations, see James, Slater \& Buckman, supra note 82.

97 See J McNiff \& J Whitehead, All you Need to Know about Action Research (Thousand Oaks, CA: Sage, 2006 ) at 9. 
research where recommendations for change are offered after the research is fully completed, action research findings are implemented throughout the research cycle. ${ }^{98}$

\section{B. Simple Steps for Action Research}

To illustrate simply how an action research process evolves, I provide an overview of practical steps for a small-scale group or individual action research project to improve practice. This process applies whether the desired change is to legal practice, law teaching, or to innovating within an organization or system. ${ }^{99}$ Action research usually starts from a sense of a practical problem. ${ }^{100}$ A crucial first step is framing (and reframing) the problem or issue to be explored. A specific research question might be posed. The next step is a discovery stage and involves collecting data about the problem to increase understanding. There are different ways to collect the data depending on the issue: qualitative and quantitative surveys, interviews and focus groups, observational research, and reviewing relevant articles, reports, studies, case files, statistics, or other appropriate documentation may be appropriate to investigate the issue. ${ }^{101}$

The next step is to generate ideas about how the issue, challenge, or problem might be tackled. There are a multitude of ways to do this - interviews or focus groups with affected individuals; brainstorming with a trusted colleague; reviewing literature and searching for approaches taken to similar issues in other disciplines, sectors, or countries; or systematic approaches like participatory design workshops or social innovation lab methods, "World Café," and many, many others. ${ }^{102}$ Next, the best options for proceeding should be assessed. Once a decision is made about which is the most promising strategy to implement, it is helpful to set out an initial project work plan about how it might be implemented. A simple project learning journal or log can continue to document how the project is actually carried outand what changes are made to the original work plan - to record data collection results - and to document reflections on what is taking place. This systematic process produces a growing understanding of the issue under investigation. Action research is most often an iterative process so that

98 See eg, Somekh \& Zeichner, supra note 81. For participatory action research, see R McTaggart, "Guiding Principles for Participatory Action Research" in R McTaggart, ed, Participatory Action Research: International Contexts and Consequences (Albany: New York State University of New York Press, 1997) 25.

99 For practical advice, see James, Slater \& Buckman, supra note 82.

100 See Gary W Kuhne \& B Allan Quigley, "Understanding and Using Action Research in Practice Settings" (1997) 73 New Directions Adult Continuing Education 23; Richard Winter, "Finding a Voice: Thinking with Others: A Conception of Action Research" (1998) 6:1 Educational Action Research 53.

101 One taxonomy of data collection techniques describes it as "the Three Es": experiencing (through observations and field notes); enquiring (when the researcher asks - interviews, questionnaires, attitudinal scales, standardized tests); and examining (using and making records - archival documents, journals, maps, audio and video tapes, artifacts, field notes). See Creswell, supra note 84 at 611.

102 For examples of methods to engage larger stakeholder groups in generative activities around possibilities, see Peggy Holman, Tom Devane \& Steve Cady, eds, The Change Handbook: The Definitive Resource on Today's Best Methods for Engaging Whole Systems (San Francisco: Berrett-Koehler, 2007). For understanding social innovation approaches, see Frances Westley, Brenda Zimmerman \& Michael Quinn Patton, Getting to Maybe: How the World is Changed (Toronto: Vintage Canada, 2007). See also David S Weiss \& Claude Legrand, Innovative Intelligence: The Art and Practice of Leading Sustainable Innovation in your Organization (Mississauga: John Wiley \& Sons Canada, 2011). 
implementing practice changes can be adjusted mid-stream if changes are not producing the desired outcomes.

Deciding how to monitor and evaluate whether the action research strategy is proving successful is an important step - what indicators might indicate that the desired change or understanding is occurring? How will data be collected and recorded and analyzed to make this assessment? Although action research is an emergent research methodology, it is still systematic, although with varying degrees of rigour depending on project needs, resources or intentions. Since it is an action-learning strategy, analyzing the collected data is an important stage that should lead to new insights and a reformulating the action plan. New information about the problem may be discovered, an assumption that led to choosing the initial method to solve the problem may have been incorrect, or the understanding of the problem may have been incomplete. Troubling data may emerge to indicate that the interim solution is not having the intended outcomes: this should lead to reflection and revising how it is being implemented. Action research is a cyclical and disciplined process of planning, implementing, observing, reflecting and evaluating, and revising of the strategy until the desired result is obtained or the project must end. It is helpful to document the results and how the project was carried out in a final report to share the knowledge gleaned from the project and to help others understand how the research led to the desired change. The report can then be shared with those interested in tackling a similar challenge so that they can build on the lessons learned.

\section{Small Scale Action Research Project Examples}

In this section, I provide a host of examples of how action research has been used to improve practice and create change with the community legal clinic legal practice sector. Our community legal clinic [CLC] has used action research internally to improve and diversify the delivery of legal services and externally to engage our local community in tackling complex human rights issues that manifest as hunger, poverty, and a lack of affordable housing. More recently, this approach has been used in joint projects to increase access to justice with community organizations, other CLCs, and Legal Aid Ontario [LAO]. I provide examples of some of these projects.

Much has been learned from our CLC's initial fledgling efforts to implement both practical and participatory action research. Before we got started on these community development projects, we had little exposure to the theory and practice of action research. Our CLC is for all intents and purposes still a law office, and the majority of our staff were trained as lawyers. It was not until we were wrapping up our first local efforts to work on poverty reduction in the early 1990s that we came to understand that what we had been doing was action research. In the past ten years, we have improved our practice of action research tremendously by integrating our emerging practical knowledge of how to carry out community-based research with the lessons learned from reading the rich literature about action research methodology. I now set how we have used an action research framework to in effect help us "put the public first," "coordinate and collaborate," "prevent and eradicate," and to "focus on outcomes." Although I do not set out these steps in detail here, in these projects, we have typically used the steps (with varying degrees of consciousness and rigour, depending on the project) that I articulated in the last subsection.

My purpose in this article is not to present comprehensive case studies. I do not elaborate on the challenges we faced, how we overcame them, or all the lessons learned. I do not wish to represent that 
the collaborative research process was always easy or rigorous; however, the challenges we faced became an integral part of the learning process and contributed to the success of these projects partly because of how we built relationships with stakeholders and enlarged our understanding of the problem. I only seek to provide examples of the problems we were trying to solve and some of the outcomes that resulted to illustrate how this approach might help with tackling the complexity of the equal justice challenges. I will demonstrate the diverse range of situations in which action research can be applied and the transformative changes that result from this collective and highly reflective approach.

For one of our first projects in the early 1990s, we wanted to bring our conservative and disparate community together more proactively around the problems of hunger and poverty, following on our clinic's efforts to help establish the community's first food bank. We wanted to encourage the best possible united action in response to local poverty that went beyond band-aid and charitable approaches to strategies that embodied justice and exemplified a human rights approach. Collaborating with community partners, we created a Task Force on Hunger and began a research and action strategy that featured door-to-door interviews, a literature review, and extensive reflective small group work to devise a local anti-poverty strategy. While we were in the process of this research, task force members through their organizations began to implement some of the ideas that were emerging, including holding legal rights conferences, publishing a guide to living on a low income, founding a child development centre, organizing an anti-poverty partnership group, and developing new public health programs. The impact of this groundbreaking work still reverberates today, including attitudinal improvements towards those who find themselves in impoverished circumstances. In addition to building stronger relationships between community organizations to better help people at risk of hunger and poverty, and empowering the people then living on a low income who were participating in the anti-poverty partnership group, the research process had additional impact. Community members learned that charitable responses were insufficient and sometimes problematic, that systemic advocacy was critical, and that changes to laws (including providing for a basic annual income and improving employment standards) were critical to reducing poverty and respecting human rights. This led to new advocacy and law reform work.

Another multi-year multi-stakeholder collaborative research and action process began in 2002 and generated a comprehensive report assessing the extent of local homelessness and insecure housing that recommended a comprehensive set of possible solutions. ${ }^{103}$ As we were producing the research report, we began to implement some of the strategies that were emerging as potentially useful from the research. These strategies were informed by surveying more than 750 people at risk of homelessness, holding focus groups, conducting a literature search, and undertaking field visits to investigate solutions in other communities, as well as a organizing a large public meeting. By processing the findings from all theis data collected from these research methods, in 2005 we generated an ambitious and responsive affordable housing action plan, encouraged new partners to build affordable housing, influenced funding decisions and local housing and welfare policies, and birthed an inclusive Affordable Housing Action Network [AHAN]. AHAN members were active in carrying out many initiatives for more than a decade. The collective reflective capacity built by the process helped build understanding, new relationships,

103 Hastings County Affordable Housing Research Project Team, "Boxed In: The Affordable Housing Crisis in Hastings County" (April 2005), online: <www.hastingshousing.com/docs/wysiwyg/Boxed-in_report.pdf $>$. Additional project details can be found online: <www.hastingshousing.com/ahan/ahan_archive_reports.cfm>. 
synergies and commitment, and leveraged in new resources and approaches to deal with many different aspects of the affordable housing crisis.

Most recently, we began using an action research approach to improve access to justice. While undertaking a local legal needs survey funded by the Law Foundation of Ontario, we discovered potential new community partners who wanted to contribute to meeting the unmet legal needs they had helped identify. ${ }^{104}$ The research question then became: "how do we work together with community partners most effectively to improve legal literacy?" Action research was used to develop an innovative local Libraries \& Justice Partnership. The collaborative engagement process strengthened relationships with our local public and courthouse librarians as "trusted intermediaries"105 and with Community Legal Education Ontario [CLEO].

As a result of the training and resourcing strategies we implemented, local librarians can now "red flag" legal issues and direct their patrons to credible online and printed legal information resources and reputable legal help. This collaboration resulted in new digital access points to legal information and help in local libraries - an issue of particular concern in rural and remote areas and for all people living on a low income with poor computer and Internet access. ${ }^{106}$ A successful provincial forum was subsequently organized in October 2015 in partnership with CLEO and the Law Society of Upper Canada's The Action Group on Access to Justice [TAG]. This initiative is being scaled up province wide and was nominated for one of the American Bar Association's access to justice awards. ${ }^{107}$ Recently CLEO partnered with the Ontario Library Association to offer innovative online training for librarians to help detect legal problems and navigate legal information resources. ${ }^{108}$ A similar access to justice and legal information initiative has also now been launched in Saskatchewan. ${ }^{109}$

Faced with the question of how to intervene earlier to prevent or to resolve emerging legal problems, a new local Rural Justice \& Health Partnership Project, launched in 2016, has generated promising results for people living in rural and small urban communities. We now more quickly reach vulnerable people who may not otherwise be aware of their legal rights. Research revealed that empirical studies

104 Pamela Cross, with Michele Leering, "Paths to Justice: Navigating with the Wandering Lost: Providing Access to Justice in Rural and Linguistic Minority Communities in South-Eastern Ontario" (March 2011), online:

$<$ http://www.communitylegalcentre.ca/about/doc/PathsToJusticeFinalReport2011.pdf >.

105 Cohl \& Thomson, supra note 21; Leering, "Trusted Intermediaries," supra note 21.

106 See Michele Leering et al, "Librarians and Access to Justice Outreach: Project Report and Resources" (October 2015), online: <www.communitylegalcentre.ca/news/2015/Librarians-and-access2justice-report.pdf> [Leering et al, "Librarians"].

107 See "Justice Innovation Event Report: Libraries and Justice Forum" (October 2015), online: <www.communitylegalcentre.ca/news/2015/Justice-Innovation-Event-Report.pdf>; Action Group on Access to Justice, "TAG's Work with Librarians Nominated for Two American Bar Association Awards" (28 December 2016), online: $<$ https://theactiongroup.ca/2016/12/please-vote/>. For further details about the project, see PLE Learning Exchange, "Libraries and Justice," online: <www.plelearningexchange.ca/libraries-and-justice/>. In 2017 CLEO partnered with the Ontario Libraries Association to develop an eight-part online training module for public librarians designed to support their contribution to access to justice.

108 Ontario Library Association, online:

$<$ http://www.accessola.org/WEB/OLA/Events/CLEO/Building_Skills_in_Legal_Information_and_Referral.aspx $>$.

109 College of Law, online: < https://law.usask.ca/createjustice/projects/Saskatchewan-Access-to\%20LegalInformation.php>. 
have linked a lack of access to justice to ill-health. ${ }^{110} \mathrm{We}$ investigated American and Australian medical/legal partnerships and then worked with local primary health care providers in community health centres, family health teams, and a nurse practitioner clinic to conceptualize this early intervention project. This co-designed project seeks to overcome the lack of awareness that poor people have of justiciable problems; difficulties faced enforcing legal rights, and challenges with a lack of access to affordable legal help and legal capability. It links health practitioners' growing concerns about the social determinants of health and health equity with information about the legal rights that impact on those social determinants: we were surprised to discover that making these linkages isn't part of the education of health professionals. To build their legal literacy, health care providers receive training to help them 'red-flag' vulnerable patients' legal issues before these problems escalate. Patients are referred directly to clinic staff for legal information and advice, and on-site legal services are also provided. Clinic staff can also work together with a health care provider and a patient to intervene proactively or to work collaboratively on potential legal problems, and also provide "secondary consultations." $111 \mathrm{We}$ also provide hands-on training to doctors trying to complete the complex government forms that are required to document eligibility for income support programs.

Although still in its infancy, the Justice \& Health Partnership project has provided unexpected spinoff effects due to the iterative and flexible nature of the action research process. Not only has the ongoing reflection with partners on the deliverables of the project initiative (a legal awareness/legal health check poster, the training sessions, and referral protocols, as examples) strengthened the partnerships, increased referrals to our clinic, and built new actionable knowledge in the staff, but there have also been other unexpected outcomes. For example, we have diversified our existing externship program for law students ${ }^{112}$ to include nursing and occupational therapy students and developed new partnerships with these university faculties. Students work directly with clinic staff, with clients, and on projects such as creating new legal rights awareness sessions for health care providers using adult learning strategies. We have provided introductory seminars to nursing classes about the links between the social determinants of health and legal rights. Our cross-disciplinary collaboration has given us access to the health profession's superior skills at program evaluation: we have learned much about how to evaluate the outcomes of our work.

Early indications were that the number of referrals by primary health care providers to our clinic had increased six-fold, and this has now increased ten-fold. Approximately 55 percent of the patients

110 Ab Currie, The Legal Problems of Everyday Life: The Nature, Extent and Consequences of Justiciable Problems Experienced by Canadians (Ottawa: Department of Justice Canada, 2007), online: <justice.gc.ca/eng/rp-pr/csjsjc/jspsjp/rr07_lal-rr07_aj1/rr07_lal.pdf >; Brittany Chaput, "Literature Review" (2015) [unpublished, on file with author]; Pascoe Pleasance, Nigel Balmer \& Alexy Buck, "The Health Cost of Civil-Law Problems: Further Evidence of Links between Civil-Law Problems and Morbidity, and the Consequential Use of Health Services" (2008) 5:2 J Empirical Legal Stud 351.

111 Secondary consultations refer to lawyers providing legal information and sometimes legal advice to non-legal professionals to assist them in dealing with their patients' problems. Liz Curran. "Lawyer Secondary Consultations: Improving Access to Justice: Reaching Clients Otherwise Excluded Through Professional Support in a Multidisciplinary Practice.” 2017 8(1) Journal of Social Inclusion 46 at 48.

112 Our legal externship program in the Faculty of Law at Queen's University started six years ago as another action research project investigating how law students might become more engaged in access to justice issues. 
referred had never dealt with the clinic (and a further 20 percent had not dealt with us in the past five years), and 93 percent of the referrals met our goal of ensuring early and timely intervention. ${ }^{113}$ Another benefit of the trust-building and growing sense of shared purpose that this project has engendered is improved medical reports for clients applying for disability benefits. We are measuring whether this will reduce eligibility appeals. Early eligibility for benefits without the need to appeal adverse decisions directly improves patient health through higher incomes, better shelter options, and improved diet, while reducing the amount of time clinic staff spend appealing adverse decisions. The time saved is now devoted to developing new legal services in areas of unmet legal need.

Several action research projects aimed at improving equal access to justice in diverse ways beyond our local community have been initiated. These have included a province-wide community legal clinic initiative to increase the efficiency and effectiveness of clinic services through better knowledge management (KnowledgeNOW), a multi-year initiative to improve the regional coordination of LAO and CLC services across five counties in Eastern Ontario, and, most recently, the Eastern and Central Ontario Clinic Transformation Project [ECRTP]. Through research into best practices in knowledge management $[\mathrm{KM}]$ and interviews, focus group, and workshops, the members of the Provincial Learning Community on Knowledge Management and Transfer identified, encouraged, and implemented better $\mathrm{KM}$, sharing and creating practices for Ontario's seventy-six CLCs. ${ }^{114}$ In addition to raising awareness of how important KM is, and provoking changes in thinking about professional learning and how we create new professional knowledge, new strategies were implemented, including KM champions in each clinic, collaborative virtual project work spaces, and other KM solutions. ${ }^{115}$

The Legal Aid Services Together project resulted in numerous initiatives to increase the accessibility, visibility, reach, and suitability of LAO-funded services in a five-county area of Eastern Ontario. Deliverables included stronger and new working relationships between LAO, community legal clinics, and community and social service organizations. This gave rise to collaborative planning to create special "road shows" of public legal information forums and new "paths-to-justice" legal literacy resources in family law matters that would not otherwise have been possible. It also spawned new referral and intake processes, a consensual definition of "holistic legal services" as a desired outcome of the initiative, new areas of legal practice, and new expectations about evaluation. ${ }^{116}$ More recently, the nine CLCs in the ECRTP adopted an action research methodology to implement sixteen different projects designed to transform legal services and meet unmet legal needs: this has signalled a new approach to collaboration to improve access to justice in Eastern and Central Ontario. "Transformation

113 Lisa Turik \& Michele Leering, "Justice and Health Partnership Project Evaluation Report: Phase II January-June 2016" (November 2016), online: Community Advocacy and Legal Centre

$<$ http://www.communitylegalcentre.ca/JHP/resources/Docs/JHP-Evaluation-Report-Jan-Jun-2016.pdf .

114 Supra note 40 [Leering et al, "Knowledge Management"].

115 The KnowledgeNOW project was designed to make better use of our scarce resources, given the alarming degree of unmet need and unequal justice for vulnerable people - we needed to find better ways to manage our knowledge so that we could share it more easily, create new knowledge more quickly, and disseminate it more rapidly. We wanted to encourage innovation, collaboration, and rapid prototyping of innovative ideas. Leering et al, "Knowledge Management."

116 See Legal Aid Ontario Five County Service Coordination Network, "Final Report to Legal Aid Ontario for Phase II" (2013) [unpublished, on file with author] 
Action Groups" were formed to carry out each action research project, and this process has spawned a new culture of innovation and reflection. ${ }^{117}$

In addition to cultivating the capacity for reflection, collaboration, and systems thinking among participants in an action research project, knowledge sharing and creating new knowledge have become important components of each project I have described. For example, we share as broadly as possible the lessons learned and the emerging actionable knowledge about promising practices, for example, for working with trusted intermediaries as valuable access to justice partners. Our reports describe our research process in varying levels of detail, provide samples of deliverables, and outline our evaluation strategies to encourage the scaling up (and local modification) of these innovative initiatives by interested others. ${ }^{118}$ In our experience, the research process has unleashed creativity, overcome resistance, and engendered hopefulness by building the energy and positive momentum for change. It has supported a new culture of reflective learning and inquiry with the partners and the organizations involved.

In this section, I presented a generic overview of action research and its key components, showing it to be a highly flexible and adaptable research strategy, amenable to small- and large-scale projects seeking to implement innovative approaches of all kinds in the justice sector. I reviewed multiple examples of the issues that have been tackled using this emergent and iterative approach to research in our legal service sector to illustrate the diversity of solutions and the constructive partnerships that are possible with a wide variety of stakeholders.

\section{CONCLUSION}

National reports have documented the emerging equal justice crisis, outlined six essential principles to guide future action, and provided ample empirical evidence of the need for profound changes in legal professional culture and in justice system priorities to better meet the needs of the public. This article has explored how embracing reflective practice and action research as potent enablers of change and innovation could transform professional culture and justice-related services. Encouraging these new professional capacities will benefit all forms of legal professional practice - whether law teaching, legal research and scholarship, conventional practice of law, court administration, legal aid service delivery, mediation and dispute resolution, and other justice sector roles. To increase leadership and action on equal justice, harnessing these capacities will help shift "professional consciousness," invigorate professional discourse, create actionable knowledge, and build leadership to help ensure the continued relevance of the profession.

Reflective practice was presented as a pedagogical innovation that will benefit legal education as well as engagement in access to justice issues. Borrowing from organizational learning theory and innovation literature, I reviewed the pivotal role that reflection plays for the ability to engage in innovative thinking, create new professional knowledge, enable learning organizations, and enhance future-forming dialogue. Reflecting on "disorienting dilemmas" to awaken an access to justice consciousness in new and

117 East and Central Region Transformation Project, "The ECRTP Story” (2016) [unpublished, on file with the author]; Eastern and Central Ontario Clinic Transformation Project (2016) [unpublished, on file with the author].

118 For two recent examples, see Turik, Leering \& Holbrough, supra note 64; Leering et al, "Librarians," supra note 106. 
seasoned legal professionals is an important contribution from transformative learning theory. Increasing the impetus to act on what Abel called the profession's greatest ethical issue offers new energy for change, a more positive sense of purpose and an enriched professional identity that includes access to justice as a "raison d'être."

Disciplined and rigorous reflection will generate new insights and create new opportunities for action at every level. According to Schön, "[t]he idea of reflective practice is an alternative to the traditional epistemology of practice; it leads ... to new conceptions of the professional client-contract, the partnership of research and practice, and the learning systems of professional institutions." 119 Adopting a reflective stance will help better articulate our theory of professional legal education and our understanding of ethical legal professionalism. Challenging our perceptions of equal access to justice requires further investigation of unmet justiciable needs. This will inspire new forms of research beyond traditional legal scholarship. Empirical studies and action research will help enact a more responsive justice system that focusses on outcomes through incorporating evaluation and evidence-based practices.

As our understanding of reflective practice in law deepens, how we think about learning and developing professionalism and our normative commitments will evolve. Not only will reflective practice and action research support a culture shift, seeding the ground for new approaches, risk taking and experimenting, they will change our perception of what constitutes legal professional knowledge. Reflective practice opens up even greater possibilities for innovative approaches in law than I consider here. It can be said of reflective practice that it animates, it interrogates, it integrates, and it generates. It increases the desire for lifelong learning and praxis and undergirds our capacity for reflective and generative dialogue, fostering creativity, innovative thinking, and supporting resilience in the face of uncertainty and complexity. The reflective legal professional is effectively continually engaging in research on the effectiveness of practice. Reflective practice becomes a "way of being, an orientation." 120

Action research was explored as a generative and accessible form of practitioner research that creates change while building understanding and developing theory. It is uniquely well suited for all forms of professional practice including legal education, traditional practice, and all justice sector roles. To illustrate its effectiveness as a catalyst for justice, unleashing the creativity of a wide range of stakeholders and building commitment, I provided non-prescriptive examples from the legal practice engaged in by Ontario's community legal clinics. These services respond to the kind of concerns documented by the national reports and exemplify the diverse professional roles that are needed now. In my experience, rather than using conventional quantitative, qualitative, or mixed methods of empirical research methodologies to solely answer questions like "does this solution work," action research uses a more exploratory, iterative, and collaborative learning cycle (which includes empirical research on effectiveness) to understand more about the problem while iteratively anwering the research question "what solution might improve this situation?" As a form of research that both diagnoses problems and develops potential solutions, it can energize justice sector players by generating a greater "systems"

119 Schön, Reflective Practitioner, supra note 24 at 345.

120 VL Chapman \& BS Anderson, "Reflective Practice" in LM English, ed, International Encyclopedia of Adult Education (New York: Palgrave MacMillan, 2005) 545. 
understanding of complex "wicked" problems, build trust and stronger working relationships, and positively encourage and then reinforce successful efforts to narrow the justice gap.

What next steps could be taken to realize the promise of reflective practice and action research as enablers of innovation? Recognizing reflective practice as a core competency for legal professionals will help shift our professional culture as well as embed expectations of disciplined reflection in our workplaces. Encouraging educators at every stage of professional legal education to use, endorse, promote, and "teach" these viable and unpretentious strategies at appropriate stages on the legal education continuum will increase their acceptance and uptake. To increase the willingness of legal professionals to engage in action research, a pragmatic approach to build this form of research would be to create succinct resource kits unique to legal education, the legal profession, and the justice sector needs. ${ }^{121}$

A professional culture of reflective inquiry offers significant collective benefits, especially for a profession committed to justice and the rule of law. Combined with the synergetic and enabling qualities of action research, the justice sector will become much better equipped to respond constructively to the "wicked problem" of access to justice. Exploring how we might best ensure that legal professionals develop these professional capabilities is an essential next step for both revitalizing our profession and for affirming that we can provide effective and innovative leadership to meet the challenge of equal justice.

121 See eg, Rowan Popplewell \& Rachel Hayman, "Where, How, and Why Are Action Research Approaches Used by International Development Non-Governmental Organisations," INTRAC Briefing Paper 32 (September 2012), online: $<$ www.intrac.org/data/files/resources/752/Briefing-Paper-32-Where-how-and-why-are-Action-Research-approachesused-by-international-development-non-governmental-organisations.pdf $>$. A simple action research kit could include a short section on the theoretical underpinnings of action research, case study examples, and a guide to carrying out action research. This guide could include a short primer on how to develop a research question and carry out a scoping review of prior knowledge on the issue. Our clinic staff have modified Fritz's "strategic tension chart" as a reflective diagnostic and planning tool for action research. Robert Fritz, The Path of Least Resistance for Managers (San Francisco: BerrettKoehler, 1999) at 43. Also useful is a project research and learning journal for ongoing documentation and reflection. Also helpful would be a primer on how to collect credible data, including examples of data collection methods such as surveys and interviews and a discussion of how to undertake high quality empirical research. A short primer on analyzing data and evaluation strategies and a sample table of contents for a project report could round out this resource. 